\title{
Oeste Metropolitano do Rio de Janeiro: debates sobre limites, fronteiras e territórios de uma região
}

Metropolitan West of Rio de Janeiro: debates about limits, borders and territories of a region

Ouest Métropolitain de Rio de Janeiro : débats sur les limites, les frontières et les territoires d'une région

Oeste metropolitano de Río de Janeiro: debates sobre límites, fronteras y

territorios de una región

\section{Marcio Rufino Silva}

\section{(2) OpenEdition}

Journals

Edição electrónica

URL: http://journals.openedition.org/espacoeconomia/16343

DOI: 10.4000/espacoeconomia.16343

ISSN: 2317-7837

Editora

Núcleo de Pesquisa Espaço \& Economia

Refêrencia eletrónica

Marcio Rufino Silva, "Oeste Metropolitano do Rio de Janeiro: debates sobre limites, fronteiras e territórios de uma região », Espaço e Economia [Online], 19 | 2020, posto online no dia 01 setembro 2020, consultado o 09 setembro 2020. URL : http://journals.openedition.org/espacoeconomia/16343 ; DOI : https://doi.org/10.4000/espacoeconomia.16343

Este documento foi criado de forma automática no dia 9 setembro 2020.

(C) NUPEE 


\section{Oeste Metropolitano do Rio de Janeiro: debates sobre limites, fronteiras e territórios de uma região}

Metropolitan West of Rio de Janeiro: debates about limits, borders and territories of a region

Ouest Métropolitain de Rio de Janeiro: débats sur les limites, les frontières et les territoires d'une région

Oeste metropolitano de Río de Janeiro: debates sobre límites, fronteras y

territorios de una región

Marcio Rufino Silva

1 Não podemos iniciar este texto sem colocá-lo, de modo mais circunscrito, a uma trajetória de pesquisa que, embora traga os acúmulos que serão expostos a seguir, ainda está em seus primeiros passos. Desse modo, expomos aqui, brevemente, os seus termos. 
Mapa 1: Oeste Metropolitano do Rio de Janeiro em 2020: limites, caminhos e fronteiras.

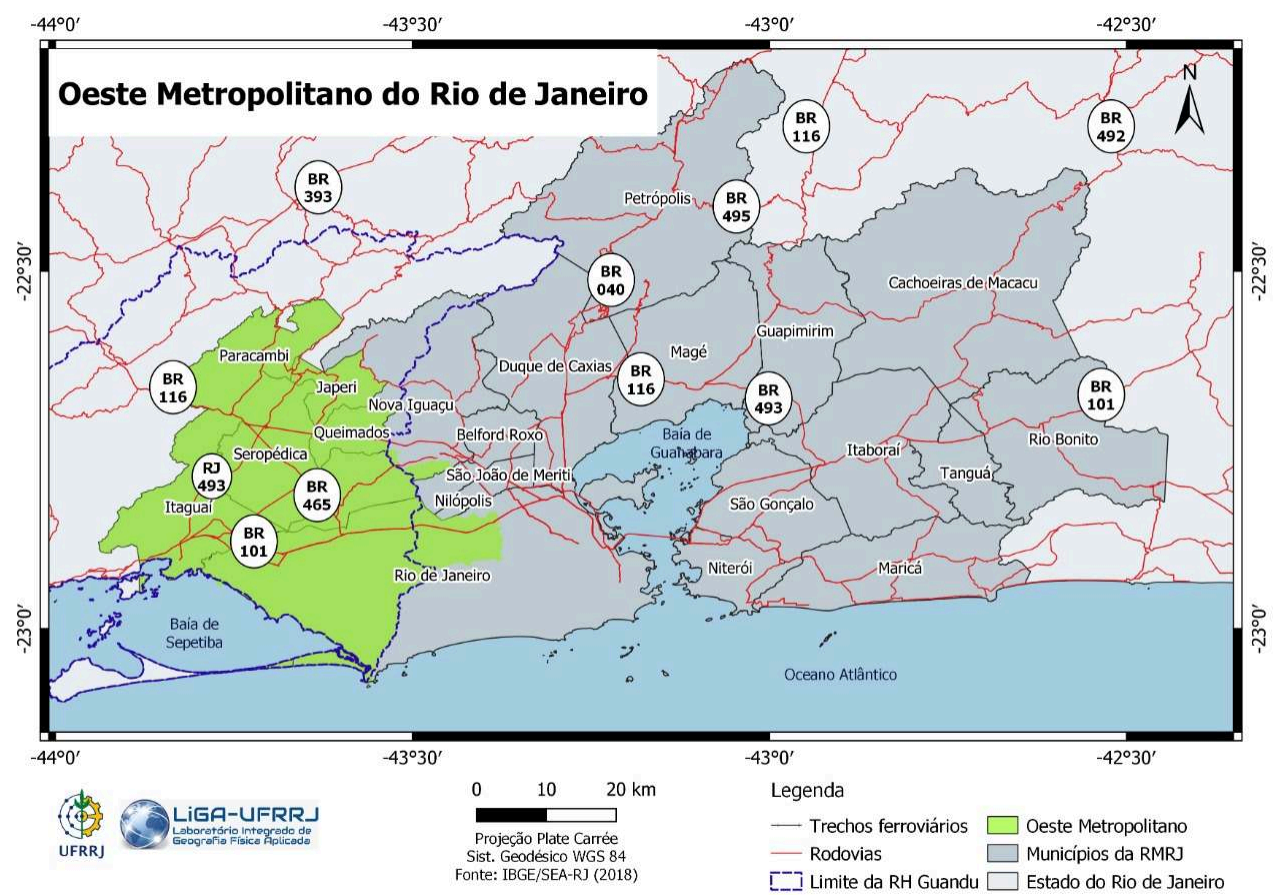

ORgANIZAÇÃO: PROF. DR. GUSTAVO MOTA DE SOUSA (LABORATÓRIO INTEgRADO dE GEOgRAfIA FÍSICA APLICADA - LIGA-UFRRJ) E PROF. DR. MARCIO RUfiNO SILVA

2 O Oeste Metropolitano do Rio de Janeiro (OMRJ), representado no mapa acima, é uma proposta analítica de (sub-)regionalização, compreendendo, a princípio, um conjunto de municípios (na totalidade de seus territórios ou parte deles) localizados no interior da Região Metropolitana do Rio de Janeiro (RMRJ). Em outras palavras, essa proposta nasce da necessidade de se compreender um processo em curso, cujos fios analíticos ainda estão por se desvendar e suas derivações teóricas ainda estão por se constituir e se consolidar. Como veremos em outros momentos deste texto, a trama empírica que cruza os diversos momentos dessa proposição teórico-analítica repõe os termos da reprodução das relações sociais de produção (LEFBVRE, 2002 [1973]). É no campo de uma crítica da economia política do espaço (LEFEBVRE, 2000 [1973]) que esse exercício de regionalização, em nossa opinião, se faz necessário. Trata-se de um espaço-tempo simultaneamente universal e particular, cuja situação geográfica muito tem a revelar acerca dos conteúdos da urbanização contemporânea brasileira, circunscrita à sua mundialidade. Portanto, é uma proposição que, no campo teórico-metodológico, traz a sua certidão de nascimento: trata-se do desvendamento de formas e conteúdos do urbano enquanto um processo que se caracteriza pela reunião, pela simultaneidade e pela dialética do espaço.

3 Essa (sub-)região, segundo nossa proposta, conforme o mapa da Figura 1, corresponde à parte oeste do atual território da Região Metropolitana do Rio de Janeiro (RMRJ). Ou seja, o OMRJ configura-se numa região que inclui a totalidade do território de cinco municípios (Itaguaí, Seropédica, Paracambi, Queimados e Japeri) e parte do território de dois municípios (Nova Iguaçu e Rio de Janeiro). A proposta analítica dessa regionalização dialoga com outras propostas preteritamente aventadas em outros fóruns e incorpora sentidos e significados de outras regionalizações pretéritas e presentes, conforme será apresentado neste artigo. Além disso, como veremos adiante, 
ela sedimenta e almeja visibilizar processos históricos de constituição particular da urbanidade contemporânea nessa fração do território da RMRJ. Por essa razão, levantaremos, neste artigo, os diferentes momentos constitutivos dessa proposta de regionalização.

No primeiro tópico, faremos um breve diálogo com algumas teorias e debates, ao menos no campo da Geografia, que se puseram a tratar das regionalizações do urbano e de temas e conteúdos da chamada "metropolização do espaço". De um modo geral, intentamos colocar em questão esse campo teórico, de modo a iluminar nossa proposta teórica particular.

5 No segundo tópico, apresentaremos diversas perspectivas e olhares sobre o OMRJ, localizando seus contornos esboçados em alguns planos e estudos promovidos, divulgados ou mesmo implantados por institucionalidades diversas no âmbito dos poderes públicos, tanto no período contemporâneo (mais especificamente, a partir do início do século 21) quanto nas décadas de 1930 e 1940, sendo este um momento que consideramos crucial na marcação de um reposicionamento desse recorte espacial dentro de um projeto de desenvolvimento local e nacional, cuja forma e conteúdo serão explicitados mais adiante. Ao final desse tópico, apresentaremos elementos constitutivos da gênese da propriedade na região, enfatizando a presença da Fazenda de Santa Cruz, expondo alguns momentos da longa história dessa fazenda em um período de quatro séculos, entre 1570 e 1970.

6 No terceiro e último tópico, indicaremos alguns elementos da gênese dos caminhos e fronteiras da região, cruzando, mais uma vez, projetos e concepções de institucionalidades públicas contemporâneas com alguns projetos concebidos entre os séculos 17 e 19, resultando na composição de uma intricada rede local de caminhos que, de certo modo, justifica-se e é justificada pela instituição da centralidade política da cidade do Rio de Janeiro (via transferência da capital da Colônia, em 1763, já no âmbito do ciclo do ouro em Minas Gerais) e, décadas adiante, consolidou a centralidade econômica nacional ao Rio de Janeiro, pelo menos durante dois séculos. Note-se que, nesse período de cerca de 200 anos, os caminhos locais e de seu "sertão oeste" se dirigiram, grosso modo e, particularmente, nos primeiros cem anos, às minas e ao escoamento da produção cafeeira, constituindo a passagem histórica de caminhos terrestres trilhados por tropas ao traçado das vias férreas e, em seguida, aos caminhos percorridos por veículos automotores, já no início do século 20.

7 Convém salientar, desde então, que a perspectiva que se adota neste artigo como um todo e, mais explicitamente, no segundo e terceiro tópicos, é o método regressivoprogressivo, anunciado pelo filósofo francês Henri Lefebvre em muitas de suas obras. ${ }^{1}$

8 Finalizando essa breve apresentação, não podemos nos esquivar de ressaltar nossas evidentes aproximações com o paradigma marxista-lefebvreano e seus derivados, incluindo as passagens pela teoria do espetáculo (DEBORD, 2003 [1967]), pela crítica radical do valor (JAPPE, 2006) e, de modo mais ou menos periférico, pela análise institucional (LOURAU, 1995 [1970]). É deste lugar que este texto é escrito e é nessa aventura, com esse recorte, que embarcamos desde já. 


\section{Regionalizações do urbano: preliminares}

9 Há cerca de 55 anos, um grupo de geógrafos franceses publicava uma obra que, segundo muitas avaliações, sedimentaria as bases de uma importante virada epistemológica na Geografia, tanto no Brasil quanto em outros países: trata-se da coletânea "A Geografia Ativa”, clássico que reuniu nomes de peso, como Pierre George, enquanto diretor da coletânea, e Yves Lacoste, Raymond Guglielmo e Bernard Kayser. No Brasil, a primeira edição traduzida data de 1966, e desde então teve considerável recepção e influência na formação de muitos quadros que produzem e difundem, ainda hoje, o paradigma de uma geografia crítica e a perspectiva teórica da produção do espaço² ${ }^{2}$. Na primeira parte da obra, os autores (ou o próprio George) esmeraram-se em trazer "problemas, doutrina e método" para discutir a pertinência, o objeto e as perspectivas metodológicas da Geografia, segundo os pressupostos hegemonicamente vigentes até então e, simultaneamente, trazendo novos debates para o corpus desse campo disciplinar do saber. Em dado momento, apresentam a noção de "situação", que:

[...] se define necessariamente em primeiro lugar em limites espaciais, mesmo quando a influência do espaço local ou regional se combina com os efeitos de uma pluralidade espacial. Mas a evolução da situação pode comportar deslocamento dos limites regionais ou locais, expansão ou retração do referido espaço. As heranças de situações anteriores não correspondem necessariamente aos mesmos dados espaciais da situação atual e, desembocando em outra situação a curto prazo, podese ser conduzido a reconsiderar a posição espacial." (GEORGE et al., 1973 [1964], p. 22).

Páginas adiante, Bernard Kayser vai trazer contornos mais precisos quanto às intenções daquela geografia que se constituía naquele momento, buscando uma definição do conceito de região, considerando o caráter múltiplo, dinâmico e diverso de tal acepção.

Uma região é, sobre a terra, um espaço preciso, mas não é imutável, inscrito em um quadro natural determinado, e que responde a três características essenciais: os laços existentes entre seus habitantes, sua organização em torno de um centro dotado de certa autonomia, e sua integração funcional em uma economia global. Ela é o resultado de uma associação de fatores ativos e passivos de intensidades variáveis, cuja dinâmica própria está na origem dos equilíbrios internos e da projeção espacial. (1973 [1964], p. 282)

11 Quase vinte anos depois desses escritos, atravessando inclusive momentos de reconfiguração do escopo da produção acadêmica da Geografia, o geógrafo britânico David Harvey, no igualmente clássico "Limits to capital" (na tradução que usamos aqui, "Los limites del capitalismo y la teoria marxista", em espanhol), tratando a respeito de um "desenvolvimento geográfico pouco uniforme", afirma que o capitalismo, ao contrário de se desenvolver em "[...] uma superfície plana dotada por todas partes de matérias primas e de uma força de trabalho homogênea, com vias e meios de transporte em todas as direções", ele se realiza em "[...] um ambiente geográfico extremamente variado, que abarca grande diversidade na generosidade da natureza e na produtividade da força de trabalho", considerando que "[...] as forças que se desencadeiam sob o capitalismo atacam, corroem, dissolvem e transformam grande parte da economia e da cultura pré-capitalista." (1990 [1982], p. 418). A região aparece, nesse momento, a partir de um complexo movimento do capital e suas frações, bem como a partir da redefinição dos termos da mobilização dos seus atributos. Em todo caso, parece que há uma constante redefinição das regiões, considerando inclusive que seu ingresso na generalização da lei do valor implica certo movimento pela 
homogeneização, ao passo que, simultaneamente e contraditoriamente, a própria diferenciação regional aparece como a negação dessa força homogeneizante. Isso engendra, inclusive, toda "[...] classe de oportunidades para a competência e o intercâmbio desigual entre as regiões" e, inclusive, "a concentração de poder econômico e político dentro de uma região pode converter-se em uma base para dominar e explorar outras regiões”, já que, “ sob a ameaça de desvalorização, cada aliança regional trata de usar a outras como meio de aliviar seus problemas internos" (1990 [1982], p. 443). ${ }^{3}$

12 Cerca de 25 anos atrás, Milton Santos lançava a primeira edição de um livro que, desde então, tornara-se outro clássico da geografia e das ciências sociais do Brasil: trata-se da obra "A Natureza do Espaço". Esse texto, objeto inclusive de traduções em alguns outros idiomas, intentou produzir "um sistema de ideias que seja, ao mesmo tempo, um ponto de partida para a apresentação de um sistema descritivo e de um sistema interpretativo da geografia" (2002 [1996], p.18), considerando a necessidade e o problema quanto à "[...] definição de um objeto para uma disciplina e, por conseguinte, a própria delimitação e pertinência dessa disciplina (2002 [1996], p. 20])".

13 Adiante, na busca pela "Geografia do Presente", mais especificamente ao tratar da da passagem do "meio natural" ao "meio técnico-científico-informacional", considerando o "conhecimento como recurso" e, em seguida, o "espaço nacional da economia internacional", entra em cena um curto e denso debate sobre a "universalidade atual do fenômeno de região". Iniciando o argumento, o autor diz que, a despeito da "vertente pós-moderna que fala de um fim do território e de um não-lugar" que propagandeia "a negação da ideia de região", "[...] nenhum subespaço do planeta pode escapar ao processo conjunto de globalização e fragmentação, isto é, individualização e regionalização". Em seguida, contrapõe a perspectiva histórica das regiões como um edifício orgânico, afeito à "territorialidade absoluta de um grupo, onde prevaleciam suas características de identidade, exclusividade e limites", onde solidariedades características deviam-se a arranjos exclusivamente locais (2002 [1996], p. 246). Contudo, ainda segundo as palavras do autor, na redefinição do ecúmeno, que é própria do processo de globalização ou mundialização, as regiões, em sua forma e conteúdo, são constantemente assaltadas no campo das mudanças, o que leva o autor a pontificar que "o que faz a região não é a longevidade do edifício, mas a coerência funcional, que a distingue das outras entidades, vizinhas ou não", e que "isso não suprime a região, apenas ela muda de conteúdo", dado que "a espessura do acontecer é aumentada, diante do maior volume de eventos por unidade de espaço e por unidade de tempo" (2002 [1996], p. 247). ${ }^{4}$

Outro importante diálogo sobre a regionalização, desta vez mais especificamente ancorada no fenômeno da urbanização, encontra-se em um texto-testemunho de Edward Soja quanto à sua própria obra, publicado há alguns anos no Brasil, intitulado "Para além de postmetropolis" (2013). Nesse escrito, Soja reitera um argumento desenvolvido ao longo de textos anteriores, sobretudo em seus livros publicados entre as décadas de 1990 e 2010, de que a "virada espacial" corresponderia a uma determinação historicamente presente desde os primeiros "assentamentos" humanos: os efeitos da aglomeração sobre a ocorrência das "revoluções urbanas" (emprestamos aqui a terminologia presente na obra "Postmetropolis", publicada em 2000), aportando, nesse processo, o que Soja denomina synekism, termo pouco traduzível ao português. ${ }^{5}$ 
Em um tom reiterativo dos escritos lefebvrianos sobre o "direito à cidade" e a "revolução urbana", Soja avalia que:

De certa forma comparável ao que aconteceu nas ciências da terra quando teorias de placas tectônicas revolucionaram um pensamento anterior a respeito do deslocamento continental, a crescente pesquisa em forças econômicas, políticas e culturais provenientes de geografias urbanas provavelmente levará a mudanças radicais tanto na economia do desenvolvimento contemporâneo quanto na geografia humana crítica, bem como na arqueologia, paleoantropologia e geohistória das sociedades humanas. (2013, p. 148).

15 Torna-se patente na argumentação do autor, em outros momentos do texto, que o surgimento desses assentamentos, desde o início da história humana, confeririam primazia à forma política do Estado (seja a cidade-Estado, seja as formas territorialmente mais extensas) e também à colonização produtiva de seus entornos, justificando, inclusive, o surgimento e desenvolvimento da agricultura nos primórdios da civilização humana.

16 Tratando desses efeitos da aglomeração, Soja discorre, em seguida, sobre o caráter da urbanização contemporânea, sobretudo nos últimos 30 ou 40 anos, trazendo o conteúdo dos "processos de reestruturação urbana", onde se verifica uma "urbanização regional policêntrica, acompanhado por um relativo declínio do que pode ser descrito como um modelo distintamente metropolitano de crescimento e de mudança urbanos", sugerindo uma "transformação da urbanização metropolitana para a regional", concluindo que "o uso de termos associados tais como cidades-região e cidades regionais crescerão em importância para a análise geográfica urbana ao longo da próxima década" (SOJA, 2013, p. 150). Uma crítica à visão dualista presente nos estudos urbanos durante boa parte do século 20 (urbano x suburbano) é acompanhada pela constatação de que, mais e mais, os antigos "subúrbios" rarefeitos pouco a pouco se densificam e se tornam mais parecidos com o velho núcleo urbano original, perfazendo uma "rede amplamente distribuída de aglomerações de variados tamanhos" ou "uma nova geografia urbana" (2013, p. 154). Em seguida, apresenta as múltiplas escalas da urbanização regional, anunciando que tem ocorrido, em vários lugares do mundo, o surgimento de "regiões de megacidades, megarregiões, regiões metropolitanas, galáxias regionais ou mesmo regiões-Estado, imensas redes regionais de aglomerações" (2013: 158).

17 No Brasil, não é pequena a quantidade de estudos que fazem essa interrelação entre o fenômeno regional e o processo de urbanização. A princípio, podemos citar os estudos de Sandra Lencioni, que advogam da existência ou da consolidação de uma megarregião englobando as metrópoles de São Paulo e Rio de Janeiro, incorporando tanto a totalidade de suas regiões metropolitanas institucionais quanto outras regiões metropolitanas ou aglomerados urbanos no entorno de ambos núcleos ou satelitizados por eles (LENCIONI, 2015a; 2015b). Na verdade, a megarregião, segundo acepção da autora, perfaz a policentralidade de vários núcleos urbanos, ou ainda de urbanidades "sem cidades" (2015b, p. 12), em uma composição de "nebulosas urbanas" (2015a, p. 35). Trata-se, ademais, da perspectiva da "metropolização do espaço", que compreende a extensão do fenômeno metropolitano para além das figuras administrativas dos municípios-sede ou mesmo dos limites político-territoriais das regiões metropolitanas. ${ }^{6}$

Quanto à RMRJ, muitos estudos têm trazido, nos últimos anos, a pertinência de se pensá-la em suas especificidades intrarregionais. Dito de outro modo, a especificidade dos processos atinentes às atividades produtivas e aos ritmos da urbanização em 
territórios específicos dessa região metropolitana têm sugerido que existem particularidades locais que certamente devem ser consideradas. Os estudos desses processos ocorrem seja pela concepção de "reestruturação territorial-produtiva", o que incluiria uma verdadeira lógica de reconversão dos usos produtivos do território, em alguns momentos pelo uso da noção de "borda metropolitana", situando nesses ambientes os novos ditames das lógicas produtivas empresariais no âmbito do capitalismo em seu estágio de financeirização (SILVA, R., 2009; OLIVEIRA, P., 2016; OLIVEIRA, L., 2019; OLIVEIRA, F. e OLIVEIRA, L., 2020, dentre outros inúmeros estudos). Os debates que são levantados, nesse caso, passam também pela ideia de que territórios economicamente ou socialmente desvalorizados, em dado período histórico, realizamse desse modo por conta de um processo de urbanização e metropolização que se esmerou em produzir ou aprofundar formas de segregação sócio-espacial e produzir verdadeiras periferias urbano-metropolitanas pouco servidas de efetiva urbanidade e pouco capazes de replicar centralidades, onde os direitos sociais mais elementares seriam alvo, inclusive, de barganhas políticas (incluindo, aí, as formas paraestatais) que vulnerabilizam ainda mais a vida das populações empobrecidas que povoam tais localidades e territórios e, além disso, o incremento dos impactos sócio-ambientais altamente negativos. No entanto, a ambiência de determinadas vantagens locacionais (supondo investimentos em verdadeiras reconversões logístico-produtivas), atreladas a subsídios e incentivos econômicos de dadas frações político-administrativas via Estado (listamos aí, mais especificamente, as políticas municipais individuais ou articuladas), somando-se à construção de atributos político-ideológicos (como, por exemplo, o pendor dos discursos desenvolvimentistas e da pretensa "sustentabilidade" ambiental), criam às vezes a sensação de que os tempos de empobrecimento e de estagnação ou mesmo desvalorização social e econômica estão ficando para trás (OLIVEIRA, L. e ROCHA, 2014). No caso da RMRJ e do território do Estado do Rio de Janeiro como um todo, no entanto, a chamada "retomada" do crescimento econômico nas décadas de 1990 e 2000 e, entre a segunda metade da década de 2000 e a primeira de 2010, a promessa de que novos tempos de desenvolvimento econômico trazidos pela conjunção de investimentos públicos e privados reposicionariam definitivamente o estado na rota da prosperidade econômica, encontrou profunda frustração de tais expectativas a partir de 2015. Seja como for, novos tempos, novos processos e novos ritmos, assim, sugerem, incentivam e proporcionam novas problematizações e novos estudos.

Os dois mapas a seguir, a propósito, ilustram dois esforços de (sub-)regionalização da RMRJ, produzidos em épocas diferentes (2015 e 2020), e que, de certo modo, derivam desses estudos. 
Mapa 2: Região Logístico-Industrial do Extremo Oeste Metropolitano Fluminense

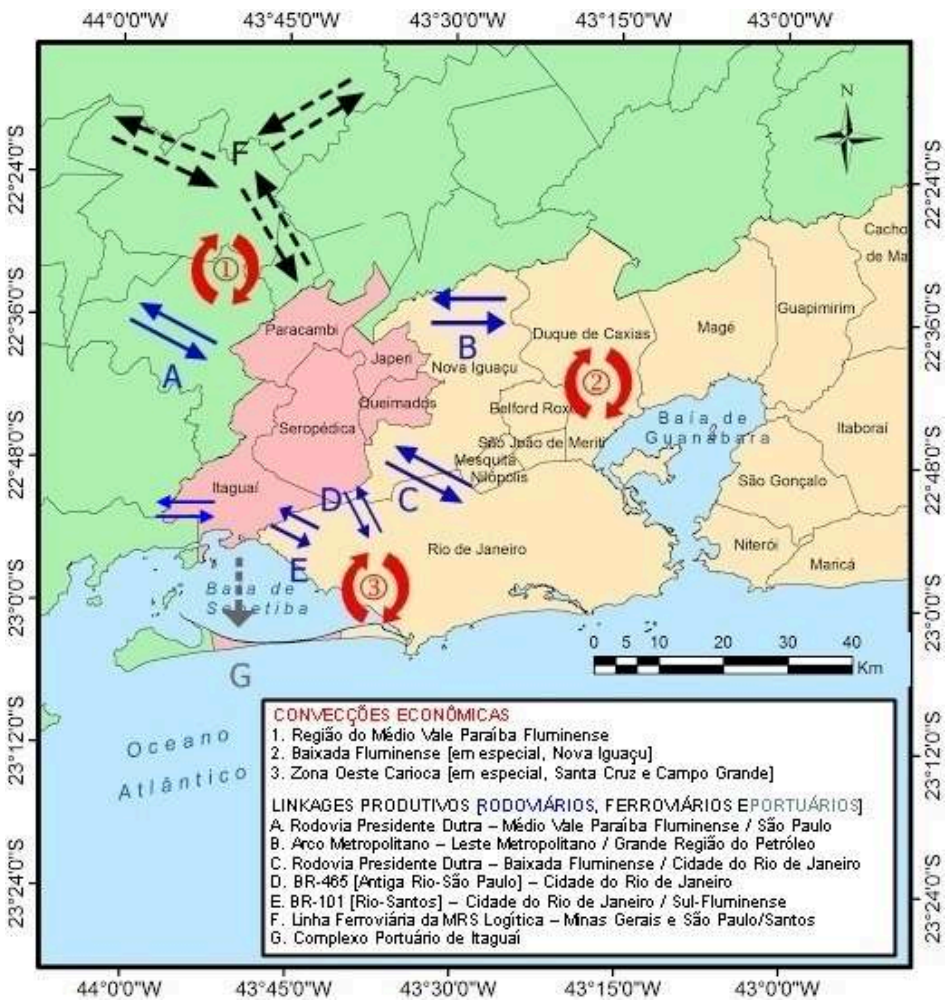

Fonte: OLIVEIRA, L., 2015

Mapa 3: Região Metropolitana do Rio de Janeiro, destacando-se a capital, o Leste Metropolitano e Baixada Fluminense, subdividida, além da Baixada "Histórica-Iguaçuana", em "Transição BaixadaLeste Metropolitano" e Extremo Oeste Metropolitano

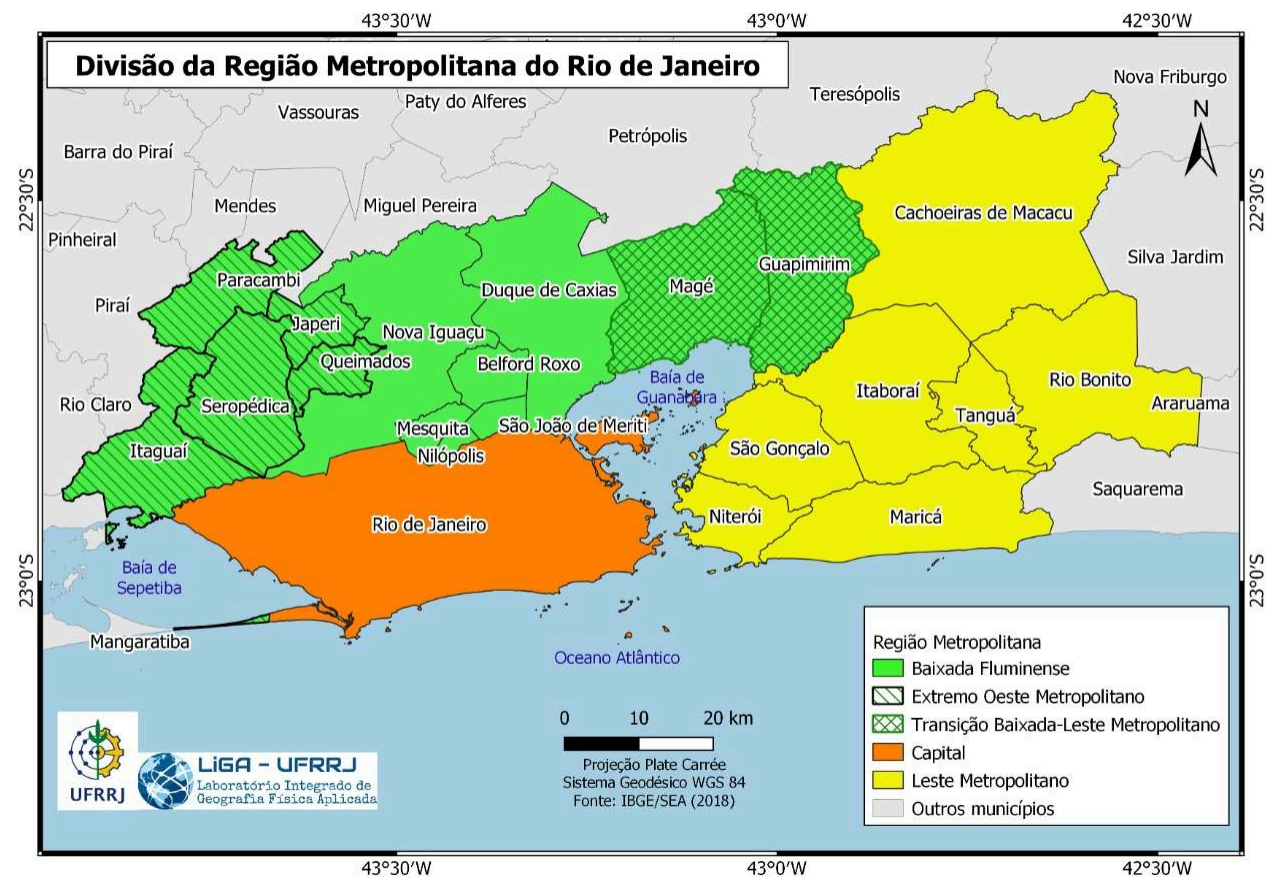

Fonte: FORTES et. al., 2020. 
Por fim, pautando-nos esse acúmulo e essas heranças teórico-metodológicas, propomos, a partir deste momento, pensar as particularidades e especificidades de um recorte cujos alguns outros de seus contornos sociais, políticos e históricos serão apresentados neste texto. Em nossa acepção, as geografias desse recorte, que neste artigo denominamos OMRJ, revelam-se a partir da intersecção também desses contornos.

\section{A vida de uma região: perspectivas e olhares sobre o Oeste Metropolitano do Rio de Janeiro}

21 Antes de tudo e conforme mencionamos anteriormente, cabe-nos salientar que não são poucos os estudos que têm levantado elementos para pensarmos a relação entre os paradigmas atuais de desenvolvimento econômico e territorial (incluindo aí, evidentemente, as suas implicações político-ideológicas) e as novas dinâmicas de urbanização do OMRJ (ALCÂNTARA, 2014; 2016a; 2016b; 2019; VIANNA, 2017; PEREIRA, 2017, entre vários outros estudos). Na verdade, um dos maiores desafios que temos quanto a esse tema, neste momento, é conseguir costurar linhas comuns entre tantos estudos, com tanta variedade de recortes espaciais (seja a escala dos municípios, como os estudos sobre Seropédica ou Japeri, ou sobre Itaguaí ou Queimados, ou ainda sobre bairros do município do Rio de Janeiro, como Santa Cruz, Campo Grande, Bangu, Guaratiba etc.) e também de recortes temáticos (da reestruturação territorial-produtiva às políticas territoriais de desenvolvimento, ou da resiliência local da produção agrícola às formas economizadas de controle e contenção social via poderes políticos institucionais ou para-institucionais, ou, ainda, das questões sócio-ambientais sugerindo a reprodução de racismos ambientais e zonas de sacrifício ao estudo das formas insurgentes de construção de uma verdadeira democracia do território etc.) que digam respeito a essa região, cuja situação, existência e movimento histórico estamos admitindo enquanto tal neste artigo.

Por essa razão, optamos por iniciar nosso tratamento específico a esse "recorte" espacial via paradigmas de sua própria regionalização. Ao mesmo tempo, intentamos cruzar os diversos critérios que sugerem elementos de coerência interna e traços distintivos entre esse fragmento espacial e os lindeiros, em seus contornos espaçotemporais. Para tanto, apresentaremos, a partir daqui, alguns elementos históricos para destilarmos a situação geográfica ${ }^{7}$ dessa região, que entendemos revelar simultaneamente perspectivas que a caracterizam como um verdadeiro território. Mais especificamente, e seguindo os ditames de um capitalismo contemporâneo financeirizado e inscrito no signo da crise estrutural do capital, um verdadeiro território economizado.

Para início de conversa, são muitos os agentes regionalizadores desse fragmento. Começamos, por exemplo, com os recortes operados a partir do Estado. Em 2000, o Decreto Estadual $\mathrm{n}^{\circ}$ 26.058, que definiu as "Macrorregiões Ambientais do Estado do Rio de Janeiro", dividiu o território estadual em sete macrorregiões, instituindo, entre elas, a "Macrorregião Ambiental da Bacia Contribuinte e da Bacia de Sepetiba", ou "MRA-2". Em 2001, uma publicação da então Secretaria de Estado de Meio Ambiente e Desenvolvimento Sustentável (SEMADS), atual Secretaria de Estado do Ambiente e Sustentabilidade (SEAS), caracterizou os limites dessa macrorregião, incluindo levantamentos sobre divisores de água, bacias confrontantes, municípios, vilas e 
povoados, relevo, geologia e solos, clima, cobertura vegetal, uso do solo e demais atributos dessa macrorregião.

Mapa 4: Macrorregião Ambiental da Bacia Contribuinte à Baía de Sepetiba - MRA-2.

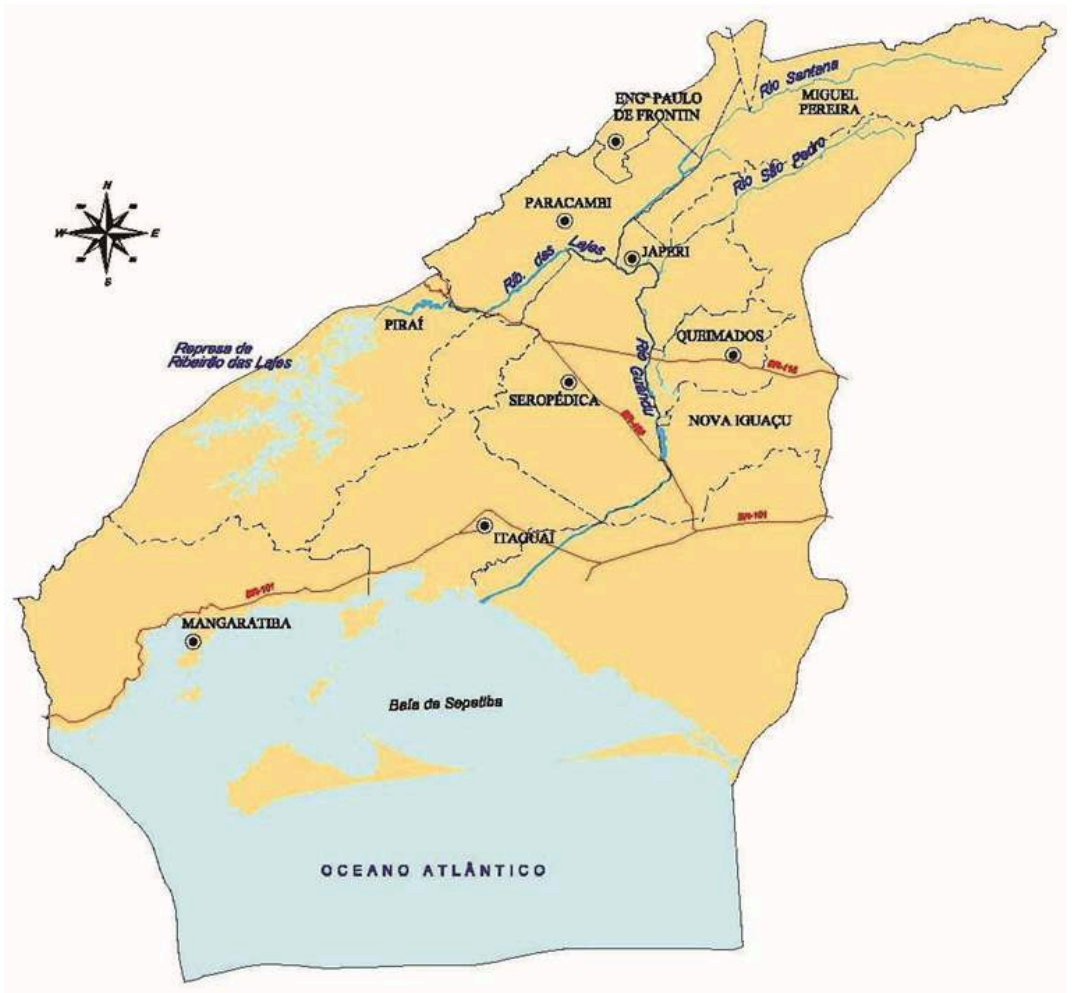

Fonte: RIO DE JANEIRO (Estado), 2001, p. 18.

Outra regionalização estadual, cujos limites são muito semelhantes à proposta anterior, consolida-se especificamente no âmbito da gestão pública dos recursos hídricos. ${ }^{8} \mathrm{Em}$ abril de 2002, com a criação do Comitê da Bacia Hidrográfica do Guandu (conhecido também como Comitê Guandu) via Decreto Estadual n 31.178, parcialmente atualizado com o Decreto $\mathrm{n}^{\mathrm{0}} 45.463$, de 25/11/2015, a porção terrestre da MRA-2 foi acrescida com a bacia do Rio Piraí (no texto do art. $1^{\circ}$ do Decreto, consta o acréscimo das "águas desviadas do Rio Paraíba do Sul e do Piraí") e, anos mais tarde, com a definição das Regiões Hidrográficas (RH) do Estado do Rio de Janeiro, mediante a Resolução do Conselho Estadual de Recursos Hídricos (CERHI) nº 18, de 08/11/2006, atualizada pela Resolução CERHI no 107, de 22/05/2013, vigente até o presente momento. Esta última estabelece a divisão do Estado do Rio de Janeiro em nove regiões hidrográficas, sendo que, quanto à Região Hidrográfica Guandu (instituída legalmente como RH-II), não houve mudanças de seus limites territoriais entre as resoluções de 2002 e 2015 (referentes à natureza, propósitos, objetivos e prerrogativas do Comitê Guandu) e as de 2006 e 2013 (referentes aos limites territoriais das regiões hidrográficas do estado). 
Mapa 5: Região Hidrográfica II (RH-II) Guandu e seus limites, incluindo corpos hídricos principais, limites políticos e sedes dos municípios do estado do Rio de Janeiro abrangidos pela RH-II

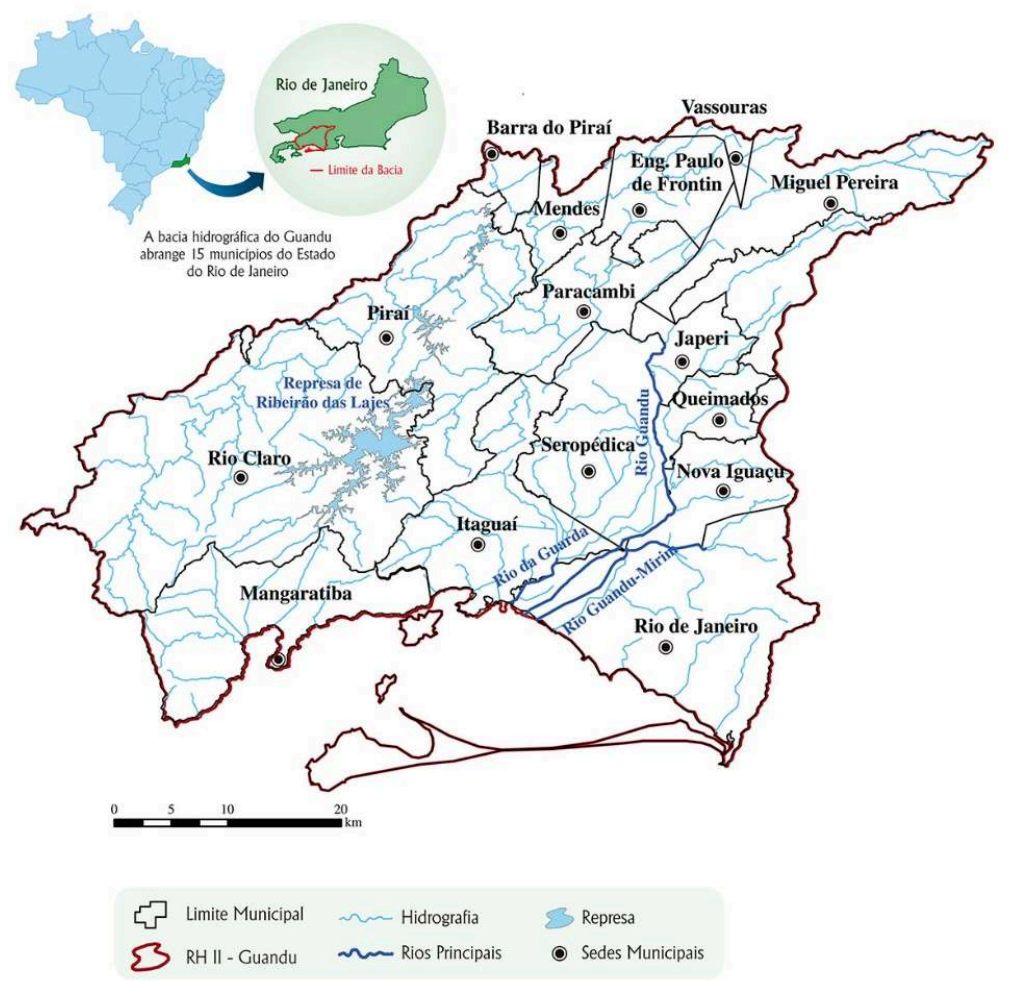

Fonte: TUBBS FILHO et al., 2012, p. 10

Ao longo da década de 2000, outra regionalização, desta vez proposta pela análise e monitoramento da qualidade do ar, foi tomando corpo e compondo agendas de pesquisa de muitos estudiosos, bem como servindo de subsídios à promoção de políticas. Em 2009, por exemplo, o "Relatório Anual da Qualidade do Ar do Estado do Rio de Janeiro" divulgou a delimitação das sub-regiões da RMRJ caracterizadas por "Bacias Aéreas", considerando que "as influências da topografia e da meteorologia" são determinantes para os padrões de circulação atmosférica local (RIO DE JANEIRO [Estado], 2009, p. 20). A esse respeito, aliás, Heitor Farias destaca que "a RMRJ possui quatro bacias aéreas que têm a qualidade do ar comprometida devido à presença da segunda maior concentração de indústrias, veículos e outras fontes de poluentes atmosféricos do país" (2013, p. 50). Em 2014, um grupo de pesquisadores da UERJ e da UNIFESP propôs, inclusive, uma nova delimitação da abrangência dessas bacias aéreas, cujo resultado expomos a seguir. 
Mapa 6: delimitação das "antigas" bacias aéreas da RMRJ, datadas da década de 2000, diante da nova proposta de delimitação. De um modo geral, a delimitação proposta pelos autores aproximase ainda mais do que entendemos constituir, de modo ainda mais aproximado, os limites do OMRJ

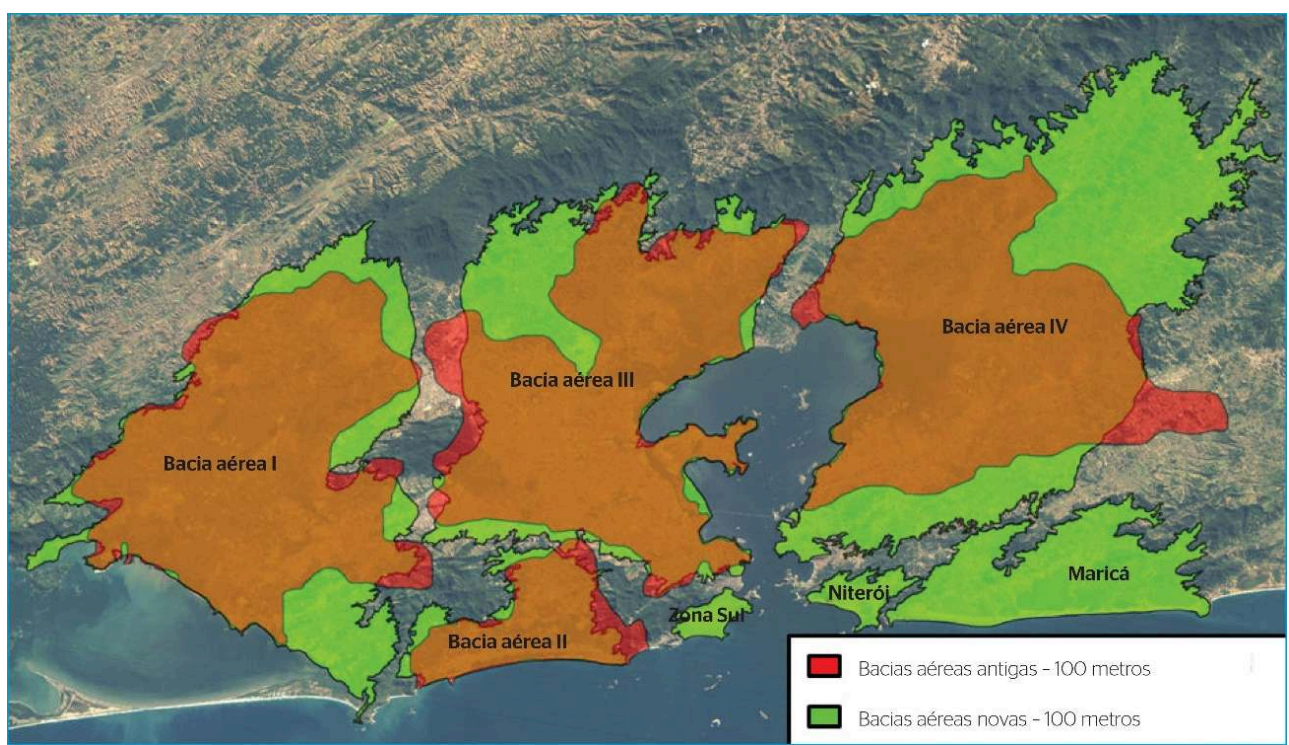

Fonte: MARTINS et. al., 2014

Em 2020, em meio aos debates sobre a concessão (ou privatização) dos serviços de abastecimento de água e esgotamento sanitário dos municípios do Estado do Rio de Janeiro atendidos atualmente pela Companhia Estadual de Águas e Esgotos (CEDAE), é apresentado, pelo Consórcio Fator / Concremat / VGP - Saneamento Rio de Janeiro, um relatório intitulado "Plano de Negócios Referencial", que estabelece os termos do projeto "Concessões Regionalizadas". Nesse relatório, o Plano de Negócios de tal concessão efetivou uma "segregação geográfica por bloco" (CONSÓRCIO FATOR, 2020, p. 7), ensejando um total de quatro blocos. O Bloco 3, cujo mapa encontra-se a seguir, corresponde justamente, grosso modo, à RH-II Guandu. Note-se, inclusive, que essa regionalização abarca a totalidade da Área de Planejamento 5 (AP5) do município do Rio de Janeiro (o que compreende as Regiões Administrativas [RAs] de Bangu, Realengo, Guaratiba, Campo Grande e Santa Cruz), destacando-a do restante do município que, segundo a proposta, pertence a outros blocos de concessão. 
Mapa 7: Bloco 3 do Projeto das Concessões Regionalizadas (em vermelho) e demais municípios e/ ou regiões atendidos pela CEDAE

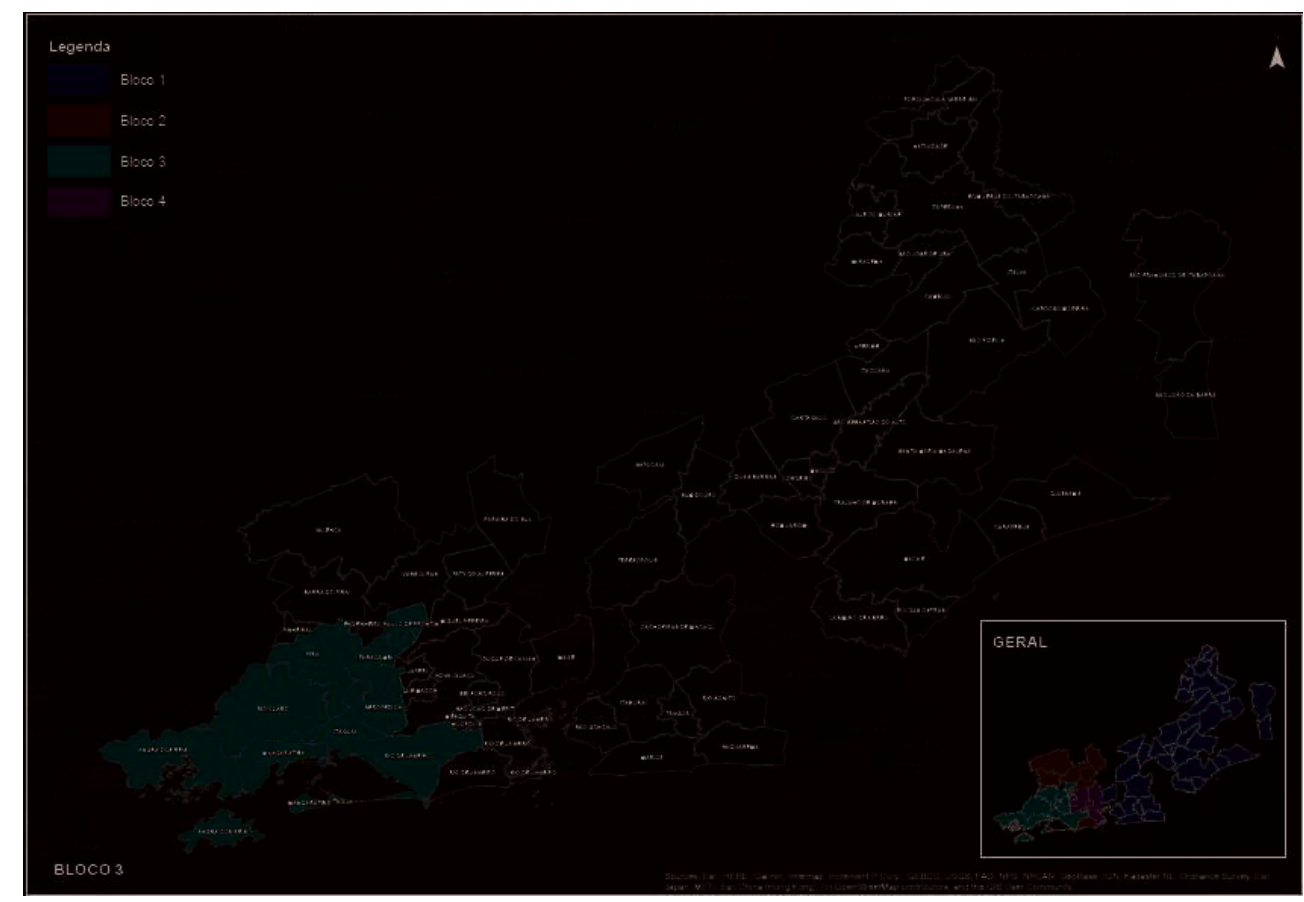

Fonte: CONSÓRCIO FATOR, 2020, p. 9

Em 2017, foi aprovado o Decreto Estadual no 46.001, que institui o "Plano Estratégico de Logística e Cargas do Estado do Rio de Janeiro" (PELC/RJ 2045) e suas futuras atualizações. 0 documento, aprovado mediante considerações no texto do Decreto quanto à "pujante infraestrutura logística já existente no território fluminense" e a alegada "vocação histórica do Rio de Janeiro para o segmento de Logística de Cargas", bem como "a estreita parceria desenvolvida em conjunto com o Banco Mundial que viabilizou a elaboração do PELC/RJ 2045 como instrumento de planejamento setorial com horizonte de 30 anos" e "a necessidade de superar gargalos acumulados na infraestrutura e de integrar os diferentes sistemas de transportes, visando consolidar o Rio de Janeiro como uma Plataforma Logística de classe mundial", traz uma interessante regionalização, cujos limites só não obedecem ao limite de um dos 92 municípios do Estado do Rio de Janeiro, como se pode verificar na figura 3, a seguir: mais uma vez, a AP5 do município do Rio de Janeiro figura em outra "região" distinta do restante do território desse município. 


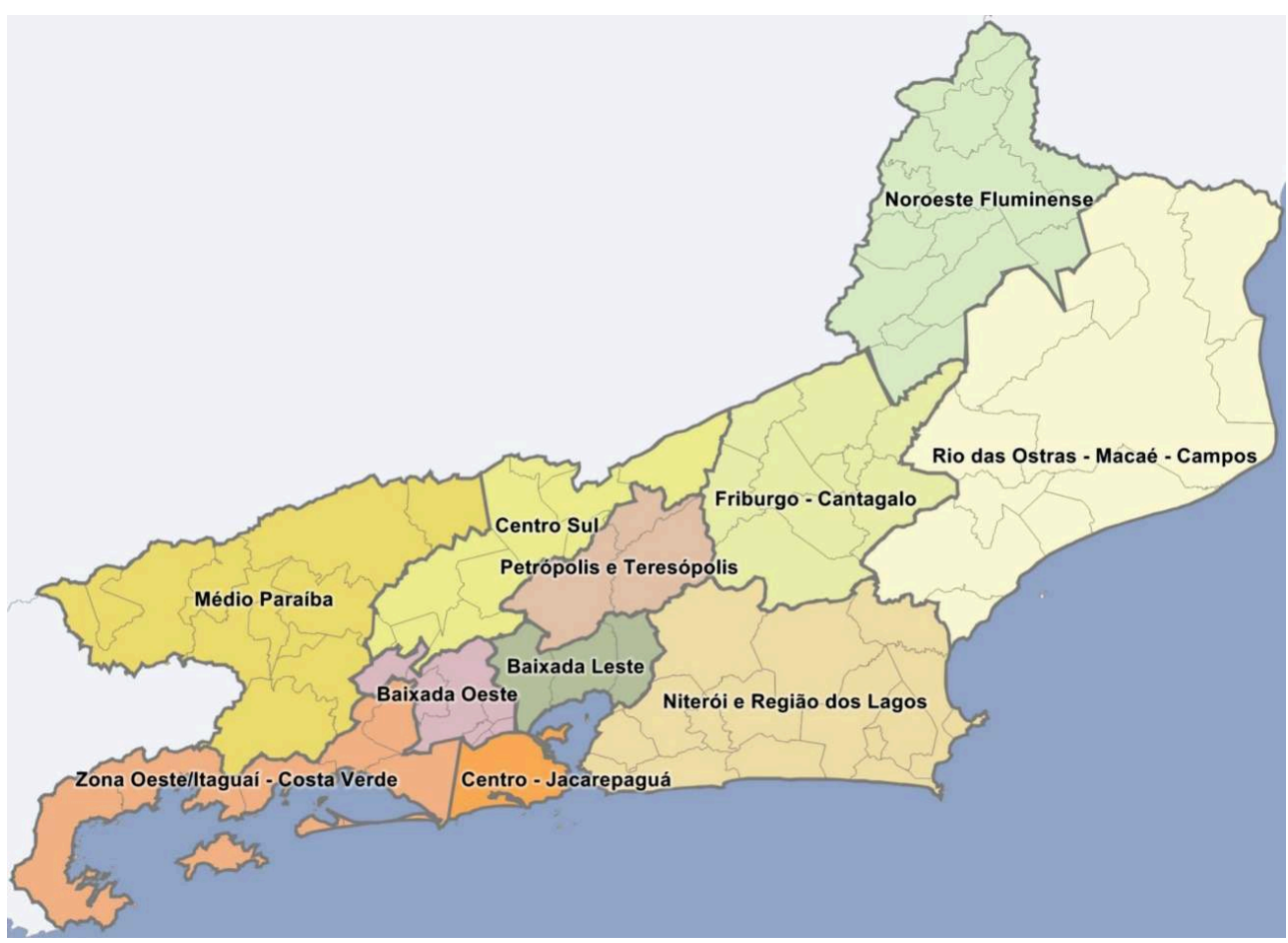

Fonte: RIO DE JANEIRO (Estado), 2016a.

O tomo I do Relatório Síntese do PELC/RJ 2045, publicado em junho de 2016, visa sintetizar o PELC "como um plano de Estado e não apenas uma lista de ações defendidas por uma gestão ou corrente política específica", destinou-se a "mostrar de forma concisa como foi construído o PELC/RJ 2045", ensejando um “documento compreensível em si mesmo ao descrever as informações principais que subsidiaram sua formulação, as metodologias empregadas e os resultados encontrados", e que não deixe "lacunas que comprometam o entendimento das várias etapas que se sucederam" (RIO DE JANEIRO [Estado], 2016a, p. 1 e 2). Adiante, o texto define as "Regiões de Interesse Logístico", informando ao leitor que, "para definir os locais onde se deveriam fazer as Oficinas e Reuniões Regionais" que deram subsídio à elaboração do plano, "o estado foi dividido em áreas em que os municípios foram agrupados buscando-se uma homogeneidade funcional e proximidade geográfica", considerando-se "critérios econômicos e a infraestrutura existente para caracterizar o Sistema Logístico, levando em consideração as distâncias, as transferências e a conectividade do transporte" (RIO DE JANEIRO [Estado], 2016a, p. 9). Considerando tais assertivas, pautadas inclusive em "reuniões e entrevistas com consultores e técnicos especialistas em transportes e economia regional do Rio de Janeiro", foram definidas 11 regiões de interesse logístico, dentre elas, a "Zona Oeste - Itaguaí / Costa Verde", que corresponde à AP5 do município do município do Rio de Janeiro (a exemplo da regionalização anterior), mais os municípios de Seropédica, Itaguaí, Mangaratiba, Angra dos Reis e Paraty. Segundo o texto, ainda:

Esta região foi agregada em função da influência do complexo portuário de Itaguaí e Angra dos Reis, das rodovias BR-101 Sul, BR-116 e BR-465 em Seropédica, da do Segmento B do Arco Metropolitano, e da Avenida Brasil, do segmento ferroviário Japeri-Porto de Itaguaí concedido à MRS Logística; e das aglomerações industriais da Zona Oeste do município do Rio de Janeiro, principalmente no Distrito Industrial 
de Santa Cruz e no Distrito Industrial de Campo Grande. (RIO DE JANEIRO [Estado], 2016a, p. 10).

Entre os anos de 2015 e 2018, a partir da construção de uma retomada do planejamento metropolitano no Estado do Rio de Janeiro, foi contratada pelo governo estadual uma consultoria para definir os termos do que ficou consolidado, mais tarde, como o "Plano Estratégico de Desenvolvimento Urbano Integrado da Região Metropolitana do Rio de Janeiro" (PEDUI-RJ), conhecido também como o plano "Modelar a Metrópole". Uma das inúmeras estratégias para a discussão do plano nas diversas localidades do território da RMRJ via realização de oficinas, audiências públicas e outros eventos, bem como na composição de instrumentos de planejamento, foi o estabelecimento das "Macrorregiões de Planejamento" (MDPs), a saber: Hipercentro, Norte, Oeste, Leste e Nordeste. Note-se, inclusive, que, segundo as justificativas dos documentos finais do PEDUI-RJ, devido à "dimensão do território metropolitano fluminense e sua grande heterogeneidade", o plano "toma, em certa medida, a forma de um plano de desenvolvimento regional". Em seguida, o texto prossegue informando ao leitor que o objetivo do estabelecimento das MDPs foi "identificar características marcantes que distinguem cada grande área metropolitana", bem como "facilitar o detalhamento de propostas estratégicas que orientaram a elaboração dos [Programas de Ação Prioritárias ou PAPs]"." Ainda, segundo o texto, "cada Macrorregião de Planejamento, via de regra, possui centralidades de segundo grau [...], de forma que estas sejam os nós estruturantes do espaço" (RIO DE JANEIRO [Estado], 2018, p. 312). Torna-se patente aqui, portanto, a importância de se considerar um processo de (sub)regionalização que inclua, necessariamente, a discussão sobre as centralidades.

Mapa 9: Macrorregiões de Planejamento (MDPs) da RMRJ no PEDUI.

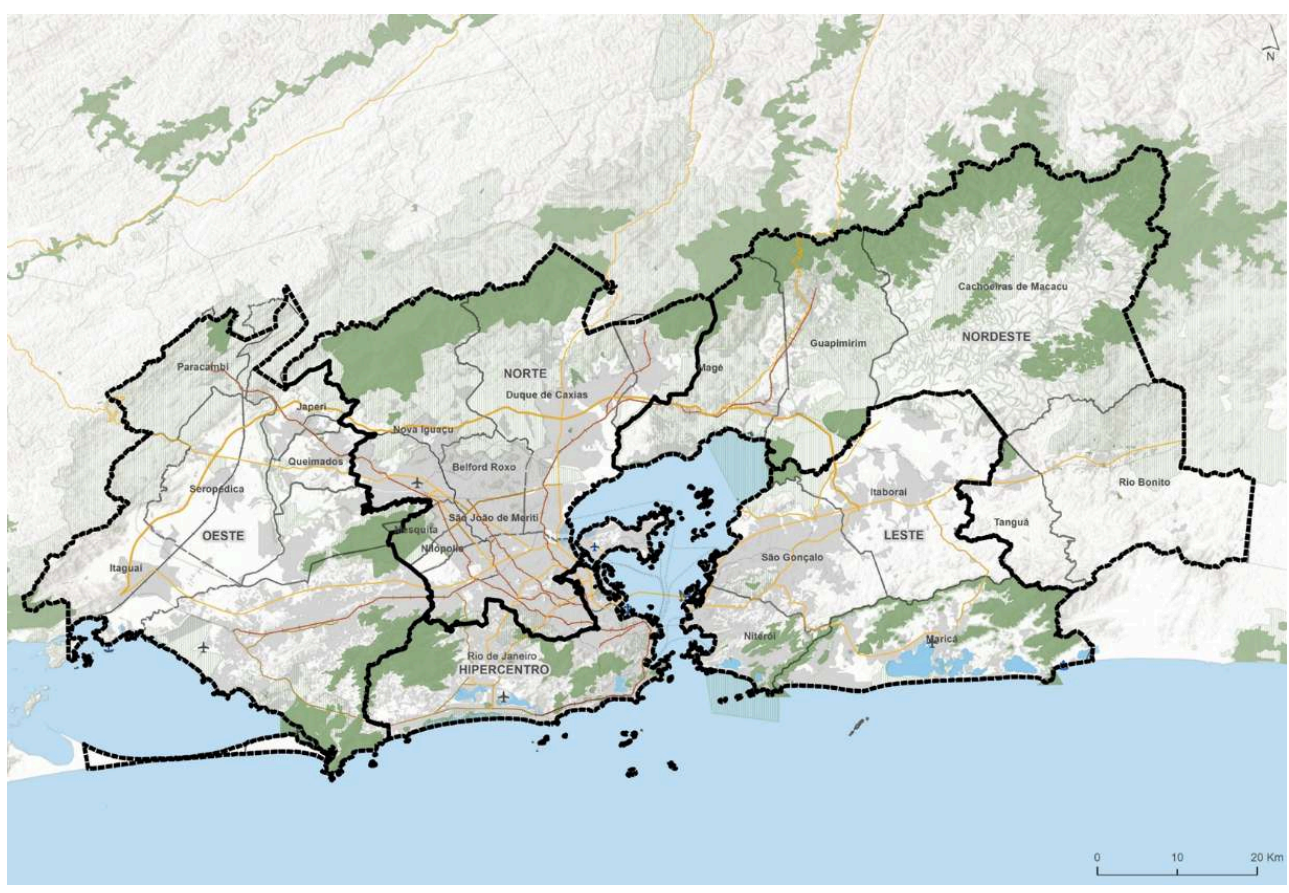

Fonte: RIO DE JANEIRO (Estado), 2018, p. 314

Seguindo o texto, "a partir do entendimento das características e tendências comuns, foi possível visualizar, de forma mais clara, as vocações de determinadas porções do território metropolitano", para as quais "foram definidas propostas e ações integradas 
que, por sua vez, orientaram a formatação das estratégias e dos projetos de intervenção que compõem os PAPs". O texto informa ao leitor, ainda, que desde os primeiros debates da equipe técnica, ainda em 2016, consolida-se a figura da MDP Oeste, que pouco a pouco vai se definindo no escopo da vasta RMRJ, cuja subregionalização é vista como necessária para "dissecar novas centralidades, avaliar seu grau de dependência e traçar estratégias intersetoriais, pautadas pelo cenário pretendido", bem como "concentrar as propostas em um único ambiente, proporcionar o diálogo e a integração entre os eixos e criar um ambiente propício para a construção de propostas integradas pretendidas". Nesse escopo, a MDP Oeste foi identificada, no PEDUI, tendo, como características comuns, a logística, os polos e as zonas de processamento industrial, bem como ter sofrido um processo de "degradação descontrolada", contornáveis, segundo o projeto (e de modo estranhamente paradoxal), com investimentos que enfoquem justamente a industrialização e a logística (RIO DE JANEIRO [Estado], 2018, p. 313-314). Note-se, ainda, que o plano identificou que a MDP Oeste, comparando-se ao restante da RMRJ, possuía, em $2016,18 \%$ da população, $26,57 \%$ da área urbana, $7 \%$ dos empregos formais, a $2^{\mathrm{a}}$ maior densidade demográfica $\left(4.309,10 \mathrm{hab} . / \mathrm{km}^{2}\right)$ e o maior tempo médio de ida e volta ao trabalho por transporte público (84 minutos). ${ }^{10} \mathrm{~A}$ MDP Oeste, igual às regionalizações anteriores, inclui a AP5 do município do Rio de Janeiro. De modo semelhante, porém, à regionalização via bacia hidrográfica (MRA e RH, conforme mostramos anteriormente), o PEDUI inclui os municípios de Queimados e Japeri, bem como as Unidades Regionais de Governo (URGs) Cabuçu (VII) e Km 32 (VIII) do município de Nova Iguaçu.

31 Avaliamos que todo esse conjunto de planos e projetos apresentados até aqui individualizam, de alguma forma, esse recorte espacial como uma região. Além disso, a despeito dos critérios ambientais explicitados, por exemplo, na definição da Macrorregião Ambiental ou da Região Hidrográfica, todos eles enfatizam o caráter urbanizado e economicamente estratégico desse recorte, bastante visível pelo seu arranjo espacial contemporâneo, fortemente pautado pelo complexo logísticoindustrial local. No entanto, um olhar mais atento a essas determinações nos leva a retroceder algumas décadas, de modo a inquirir a gênese dessa base econômica e desse urbano. Podemos por perguntar, nesse sentido: que relações condicionaram ou produziram essa urbanização? O que subsiste, nessa região, nos termos de uma ruralidade? Ou, melhor ainda, que relações podemos estabelecer, nesse corte espaçotemporal, entre o rural e o urbano?

Retrocedendo algumas décadas, chegamos a duas interessantes noções sobre esse território que ora denominamos OMRJ. Em 1936, por exemplo, notabilizou-se a publicação do livro "O Sertão Carioca", pela Imprensa Nacional, em colaboração com o Instituto Histórico e Geográfico Brasileiro, de autoria do escritor, desenhista, escultor, professor e "naturalista autodidata" Armando Magalhães Corrêa. Segundo Sarmento (1998), Corrêa pintava o dito "sertão" com as cores de um pensamento que, de certo modo, dicotomizava a "civilização" moderna, circunscrita aos bairros centrais e periféricos do então Distrito Federal, e o estilo de vida rústico e simples de "sertanejos" que viviam a poucas horas do então centro político e econômico do Brasil; além disso, Sarmento atribui a Corrêa a descrição desse estilo de vida como algo idílico e pitoresco aos olhos das elites que consumiam seus escritos do periódico carioca Correio da Manhã. Nota-se, também, traços de um nacionalismo que buscava a "essência" ou o "coração da brasilidade" nesses povos que, embora vivessem geograficamente muito próximos, aparentemente viviam à margem da dita "civilização urbana" simbolizada 
pelo núcleo central da capital. Do mesmo modo, grassam as visões negativas de elementos estranhos a esse bucólico lugar: os estrangeiros e os turistas cariocas, bem como o abandono das populações por parte dos poderes públicos quanto às suas necessidades elementares (saneamento, escolas, assistência médica etc.), em um clara contradição, no pensamento do autor, entre um cientificismo iluminista e um romantismo idealista (SARMENTO, 1998). Note-se, no entanto, que essas terras, que ainda não haviam sido plenamente alcançadas pelo crescimento urbano ou mesmo a instituição de um modo de vida de caráter metropolitano, Franco e Drummond (2005) localizam em Corrêa um projeto de instituição de avançados mecanismos preservacionistas daquelas paisagens de matas, restingas e outras formações naturais, incluindo também a participação da população residente nessa tarefa, e isso três anos antes da instituição da primeira unidade de conservação no Brasil. ${ }^{11}$ De todo modo, o riquíssimo material levantado por Corrêa e os instigantes debates que suas proposições levantam até os dias atuais, a despeito de suas controvérsias, conforma mais um interessante esforço de regionalização, manifesto no cartograma a seguir:

Mapa 10: o "Sertão Carioca"

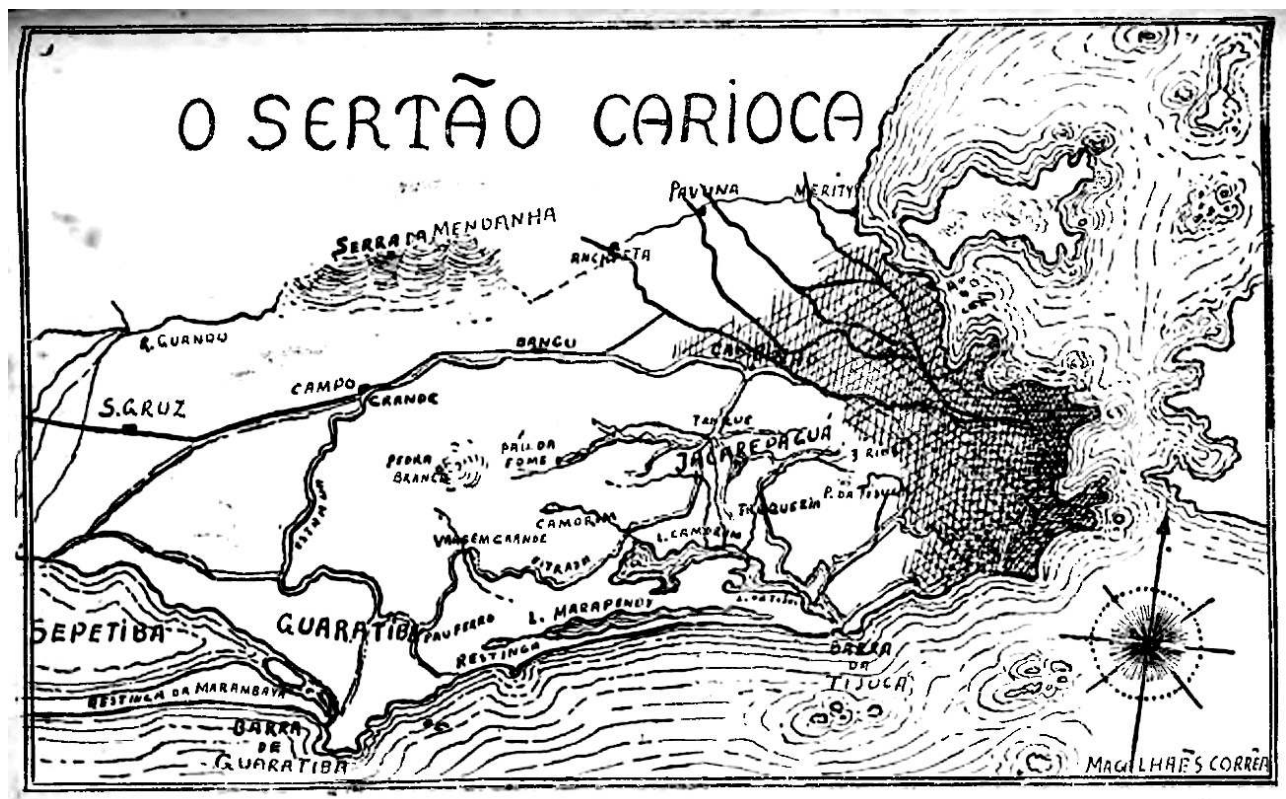

Fonte: CORRÊA, 1936, p. 272.

Ainda nessa época, as intervenções das comissões de saneamento da Baixada Fluminense, em curso ao menos desde o século 19 (SOUTO, 2016), solicitaram, igualmente, uma divisão territorial e regional quanto às suas políticas, consolidada nos relatórios assinados pelo engenheiro Hildebrando de Góis, nas décadas de 1930 e 1940: em seus estudos, as terras baixas do Estado do Rio de Janeiro, compreendendo territórios que se estendiam de São João da Barra, na foz do Rio Paraíba do Sul, até os limites dos municípios de Mangaratiba e Itaguaí, correspondiam à totalidade do que se convencionou chamar, naquele momento, de "Baixada Fluminense". Nesses estudos e nessa regionalização, a "Baixada de Sepetiba" adquiriu sua própria individualidade e sua abrangência territorial correspondeu, grosso modo, à abrangência das macrorregiões, apresentadas parágrafos atrás, nos projetos de intervenções públicas no século 21, conforme mapa a seguir: 
Mapa 11: Planta geral da Baixada Fluminense e, em destaque, a Baixada de Sepetiba

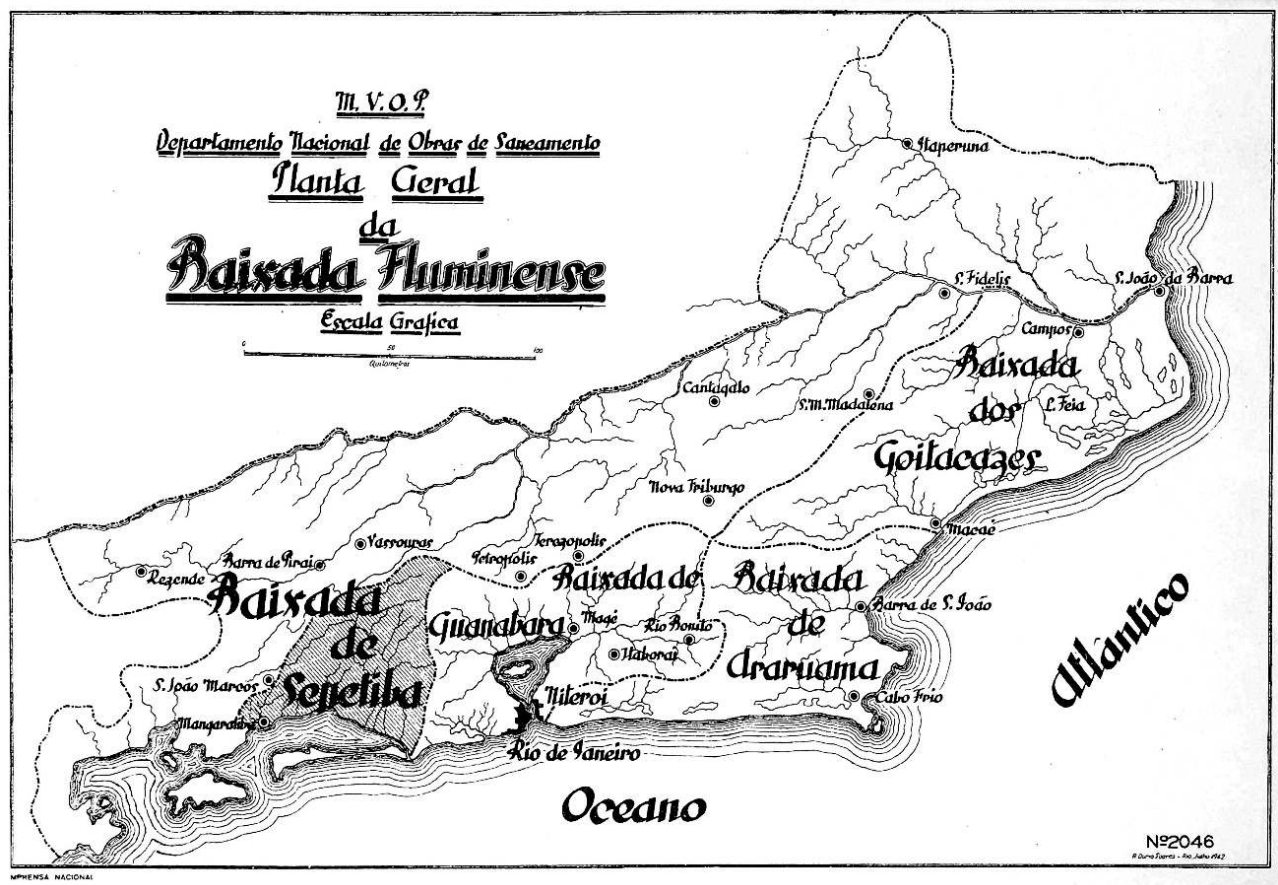

Fonte: GÓES, 1942, p. 7.

Mapa 12. Planta aerofotográfica da região da Baixada de Sepetiba, destacando áreas de brejos e alagadiços, antes das obras da Comissão de Saneamento de 1933

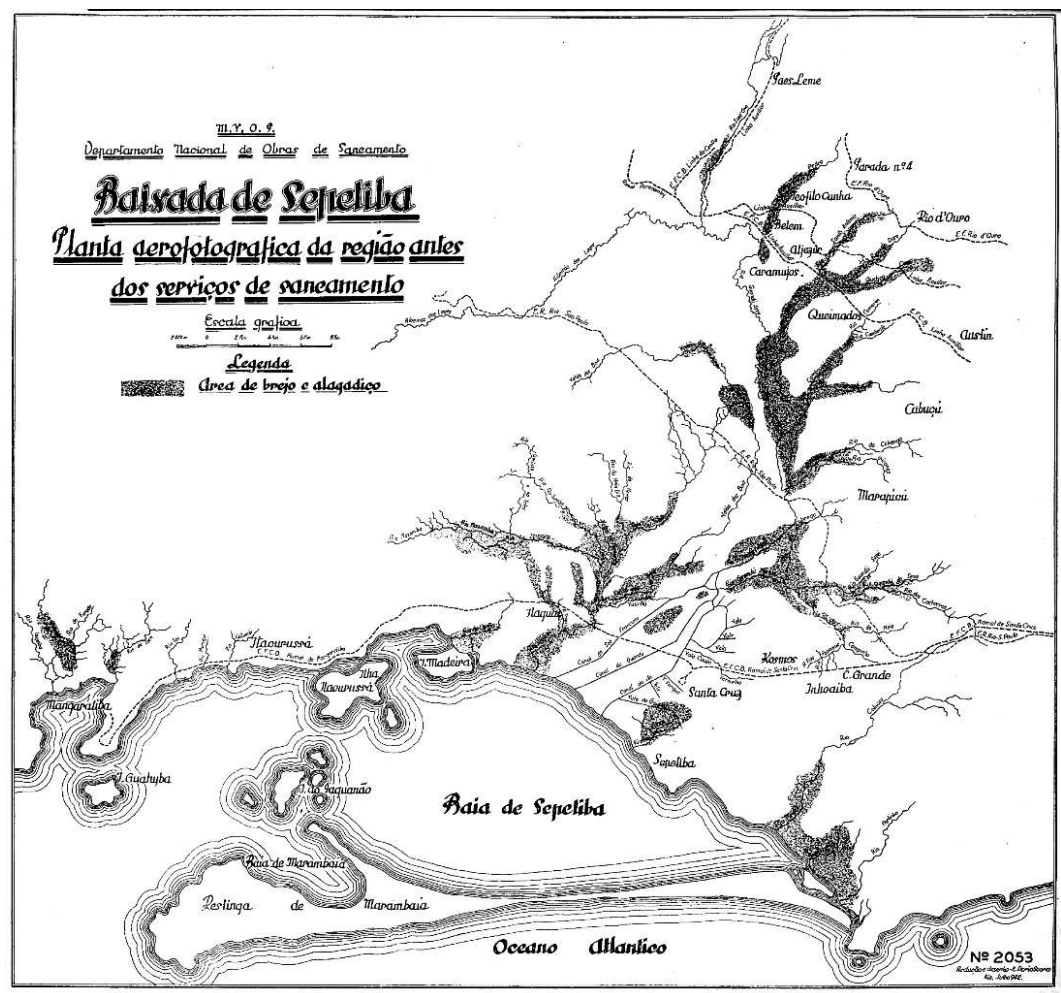

Fonte: GÓES, 1942, p. 28. 
34

relatório “A Baixada de Sepetiba”, publicado em 1942, Goés faz um balanço das ações da "Comissão de Saneamento da Baixada Fluminense", constituída no governo constitucional de Getúlio Vargas, a partir de 1933, embora as intervenções tenham se iniciado efetivamente na região apenas em 1935, segundo o texto. Nesse relatório, são apresentados também os "empreendimentos anteriores", referindo-se mais especificamente às comissões de saneamento precedentes, cujas ações são detalhadas pelo menos a partir de 1898. Quanto aos trabalhos dessas comissões anteriores, avaliava o autor que uma sequência de descontinuidades administrativas ocasionou insucessos nos trabalhos de desobstrução e desassoreamento dos cursos d'água e eliminação de charcos e demais áreas brejosas e pantanosas; além disso, o relatório traz críticas à restrição geográfica das intervenções anteriores à localidade de Santa Cruz, no então Distrito Federal, desconsiderando outras localidades a montante dos rios e demais cursos d'água tributários da baía de Sepetiba (GÓES, 1942, p. 55-59). Cumpre destacar, ainda, que o referido relatório faz menção ao "exame minucioso" que aquela comissão então vigente faria das "várias causas de insucesso dos empreendimentos anteriores, ressaltando, em primeiro plano, a deficiência de estudos, mormente no que concerne ao regime dos cursos d'água naturais" (GOÉS, 1942, p. 65). O que estava em voga, naquele momento, era uma mudança na diretriz de ação e estratégia estatal sobre aquele território: tratava-se, enfim, da construção e a implantação de um verdadeiro projeto de desenvolvimento econômico local via aproveitamento do potencial agrícola daquelas terras, inclusive via políticas de implantação e sustentação de colônias agrícolas, incluindo aí a transferência da Escola Nacional de Agronomia (ENA), então localizada no município do Rio de Janeiro, para as terras lindeiras à Estrada Rio-São Paulo. Aliás, fotografias aéreas da construção do campus e de alguns de suas edificações mostram justamente o gérmen do atual campus Seropédica da Universidade Federal Rural do Rio de Janeiro. ${ }^{12}$

que guardava aquele território, no entanto, que traria tanto interesse nas investidas do então governo Vargas em sua recomposição econômica? Uma das respostas a essa pergunta, talvez, esteja justamente no fundamento fundiário que alicerçou essa região desde, pelo menos, o início da colonização brasileira, ainda no século $16 .{ }^{13}$ Boa tarde daquele território, ora chamado Baixada de Sepetiba, ou Macrorregião Ambiental ou Hidrográfica Guandu, ou Macrorregião Oeste ou, segundo o que defendemos neste texto, Oeste Metropolitano do Rio de Janeiro, consistia, grosso modo, nas terras da Fazenda de Santa Cruz.

A Fazenda Santa Cruz, que até meados do século 19 estendia-se de do atual bairro de Sepetiba, no município do Rio de Janeiro, até atingir as terras de Vassouras e Barra do Piraí, englobando a totalidade do território dos atuais municípios de Piraí, Itaguaí, Seropédica, Paracambi e Mendes, bem como englobando partes dos atuais municípios de Queimados, Japeri, Nova Iguaçu, Engenheiro Paulo de Frontin e Rio Claro, estendiase cerca de $70 \mathrm{~km}$ na direção Norte-Sul e $35 \mathrm{~km}$ na direção Leste-Oeste, perfazendo um total de, aproximadamente, $1.625 \mathrm{~km}^{2}$ de extensão territorial (ENGEMANN et al., 2013, p. 8). 
Mapa 13: Fazenda de Santa Cruz, século 19. Destaque ao "Caminho de S. Paulo", ao sul, e o leito do Rio Paraíba do Sul, ao norte da Fazenda.

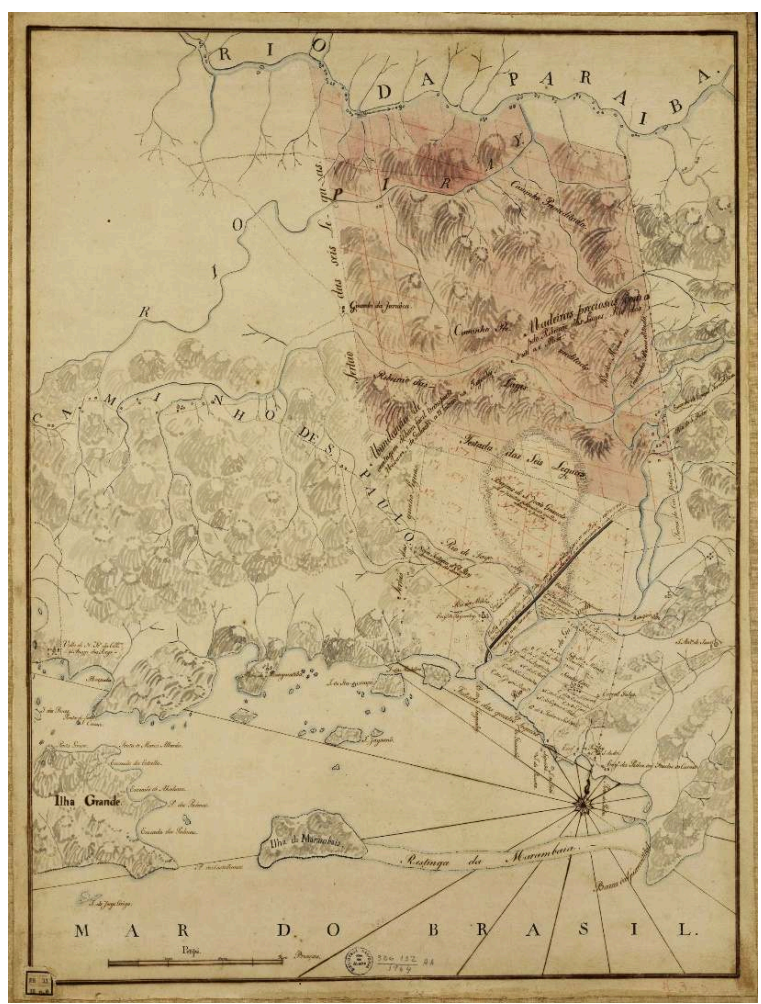

Fonte: Acervo Digital da Biblioteca Nacional. Disponível em: http://objdigital.bn.br/objdigital2/ acervo_digital/div_cartografia/cart326132/cart326132.jpg. Acesso em 29 de julho de 2020. 


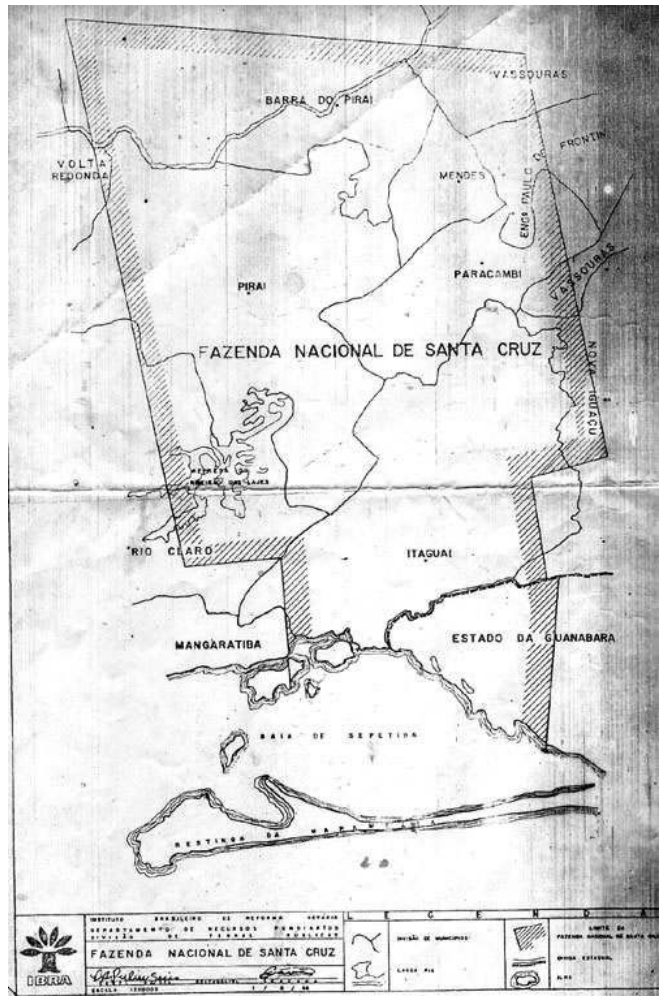

Fonte: Instituto Brasileiro de Reforma Agrária (IBRA), 1966.

Não são poucos os estudos, ao menos no campo da historiografia, que abordam os aspectos políticos, sociais e econômicos do território direta ou indiretamente abrangido pela Fazenda que, por sua vez, tanto marcou o processo de constituição dessa região. Certamente, não nos furtamos de colocar, inclusive, a sua centralidade de sua presença nas lógicas que instituíram formas economicamente produtivas na guarida de seu território.

Logo no início da colonização da América Portuguesa, estabeleceu-se a sesmaria de Guaratiba, "com quatro léguas de extensão, doada em 1567 a Cristóvão Monteiro, primeiro ouvidor-mor do Rio de Janeiro" (FRIDMAN, 1999, p. 186). Entre essa data e o início do período republicano no Brasil, no final do século 19, essa Fazenda foi repassada, em parte, à Companhia de Jesus, no final do século 16, e acrescida em área mediante aquisição de terras lindeiras, ao longo do século 17. Note-se, ainda, que já naquele período, os jesuítas, fazendo uso de mão-de-obra escrava, empreenderam obras de saneamento de boa parte dos terrenos alagadiços da Baixada de Sepetiba, tornandoos produtores de vários gêneros agrícolas (ALONSO, 1960, p. 400). Desde o início das atividades da Fazenda e sua administração centralizada, esse largo território ficou a cargo também da produção agrícola via assentamento de foreiros. Em 1759, com a expulsão dos jesuítas do Brasil, essas terras são incorporadas aos bens da Coroa Portuguesa, que a renomeou "Fazenda Real de Santa Cruz" e, partir de 1761, ficou subordinada diretamente ao Vice-Rei (FRIDMAN, 1999, p. 189). Note-se, também, que a chegada da Família Real Portuguesa em 1808 ensejou nova organização à Fazenda, criando novas estruturas administrativas e concedendo muitos aforamentos a pessoas vinculadas aos interesses clientelistas do poder central, incluindo amigos pessoais de membros da corte, instituindo moedas de troca a seletos membros da clientela que 
tomavam posse das melhores terras. Outra importante mudança no tempo da chegada da corte de D. João VI àquelas terras foi a sua conversão em terras de veraneio da Família Real (e isso ensejou, inclusive, uma série de melhoramentos na então estrada real que ligava a corte a Santa Cruz) e também a ocupação residencial de caráter urbano em Santa Cruz, inclusive com a realização de alinhamentos viários e estabelecimento de normas de edificações locais. Após todas essas transformações locais, destacamos, também, as experimentações industriais na Fazenda, com a revogação da proibição de indústrias no Brasil, em 1810, e, incluindo aí, a instalação da Companhia Seropédica Fluminense (ou, conforme Fróes [2004], o "Estabelecimento Seropédico de Itaguaí"), nas terras da então vila de Itaguaí, cuja produção local de bicho-da-seda e tecidos operou entre 1844 e 1863 (FRÓES, 2004; FRIDMAN, 1999, p. 198-201). Note-se, igualmente, que ciclos de prosperidade e decadência econômica, bem como interesses políticos de diversas ordens que seguiam tais ritmos econômicos ocorreram em vários momentos em toda a história da Fazenda Santa Cruz, ao menos até o início do século 20. Trata-se de uma história que certamente está a merecer uma revisita constante por parte de pesquisadores e demais interessados em compreender lances decisivos da história da propriedade no Brasil.

Avançando algumas décadas, a partir da década de 1930, destaca-se a criação do Núcleo Colonial de Santa Cruz (NCSC), cujo estabelecimento, segundo estudo da geógrafa Maria do Carmo Pereira Galvão, "[...] deveria abrigar colonos nacionais e estrangeiros que se dispusessem a trabalhar e colonizar essas terras públicas". Em 1948, ainda, "dividiu-se o núcleo em dois setores: Seção Piranema, compreendendo as terras situadas no Estado do Rio, e território emancipado, ou seja, a área locada no então Distrito Federal". Ainda, segundo a pesquisadora, no momento em que escrevia seu texto, no início dos anos 1960, "apesar das condições favoráveis de solo [...], o aproveitamento agrícola tem sido muito deficiente, e isso se deve, sobretudo, às más condições de drenagem"; em seguida, completa a autora que "[...] a falta de assistência técnica e econômica ao núcleo [...] é responsável pelo desinteresse dos colonos pela lavoura, que ano a ano se acentua" (GALVÃO, 2009 [1962], p. 199). No entanto, há que se considerar que essa experiência de colonização agrícola no local, a despeito da "incerteza de iniciar uma nova vida em sítios em Santa Cruz/Itaguaí" e do fato da condição de colono se ver "[...] prejudicada pela má gestão dos administradores e pela força das inundações", houve a construção local, pela ação dos colonos, de "[...] possibilidades e estratégias a serem encampadas e desempenhadas pelos colonos e suas famílias", o que escapava, muitas vezes, às determinações dos poderes governamentais. (SILVA, H., 2017, p. 19). ${ }^{14}$ Por fim, a partir do final dos anos 1960, "todos os lotes do núcleo colonial de Santa Cruz foram emancipados" (leia-se como a passagem das terras ao sistema jurídico convencional) e isso teria favorecido, a partir de então, uma configuração de mosaicos paisagísticos afeitos aos loteamentos, implantação de conjuntos habitacionais, industrialização e favelização da região, bem como uma "zona rural com sérias dificuldades de manutenção" (SILVA, H., 2017: 33). 
Mapa 15: Município de Itaguaí em 1952, que, à época, englobava o território do atual município de Seropédica (emancipado em 1995) e a maior parte do atual município de Paracambi (emancipado em 1960). Destaca-se, em verde, ao sul do então município, a "Seção Piranema" do NCSC,

localizado entre os atuais limites dos municípios de Seropédica e Itaguaí. Mais ao sul, destacamse os limites do "território emancipado", nos atuais limites do bairro de Santa Cruz, município do Rio de Janeiro.

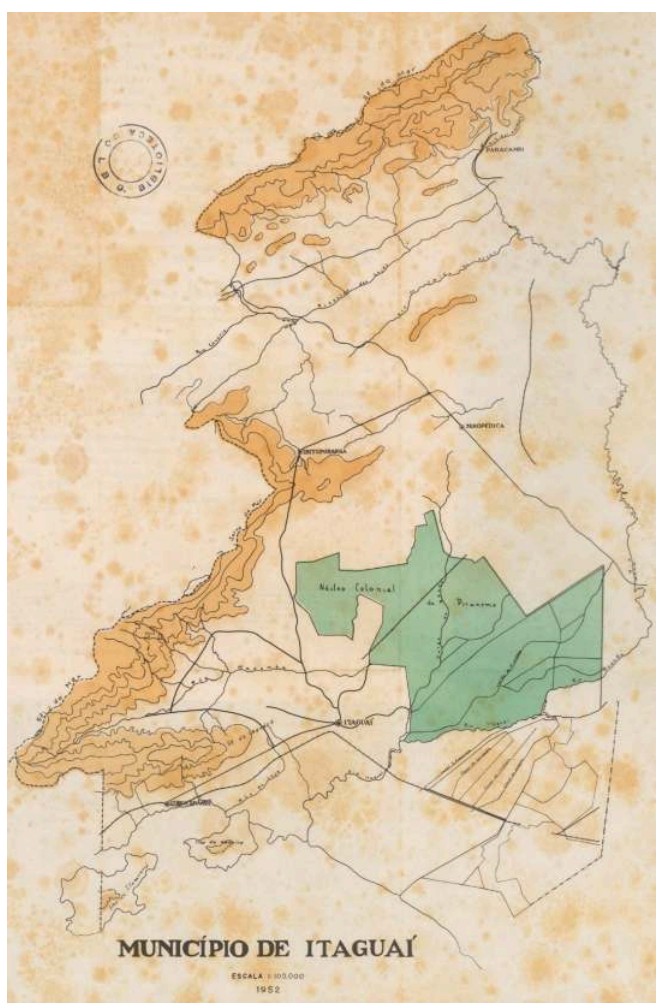

Fonte: ALONSO, 1960, p. 430 
Mapa 16: Município de Itaguaí em 1956. Além do NCSC, destaca-se, pouco mais ao norte, atravessado pela Rodovia Presidente Dutra e ladeado pelo rio Guandu e limites municipais com Nova Iguaçu (o que corresponde aos atuais limites entre os municípios de Seropédica e Queimados) o Núcleo Colonial Santa Alice, criado pelo Decreto Federal $n^{\circ} 36.806$, de 25/01/1955.

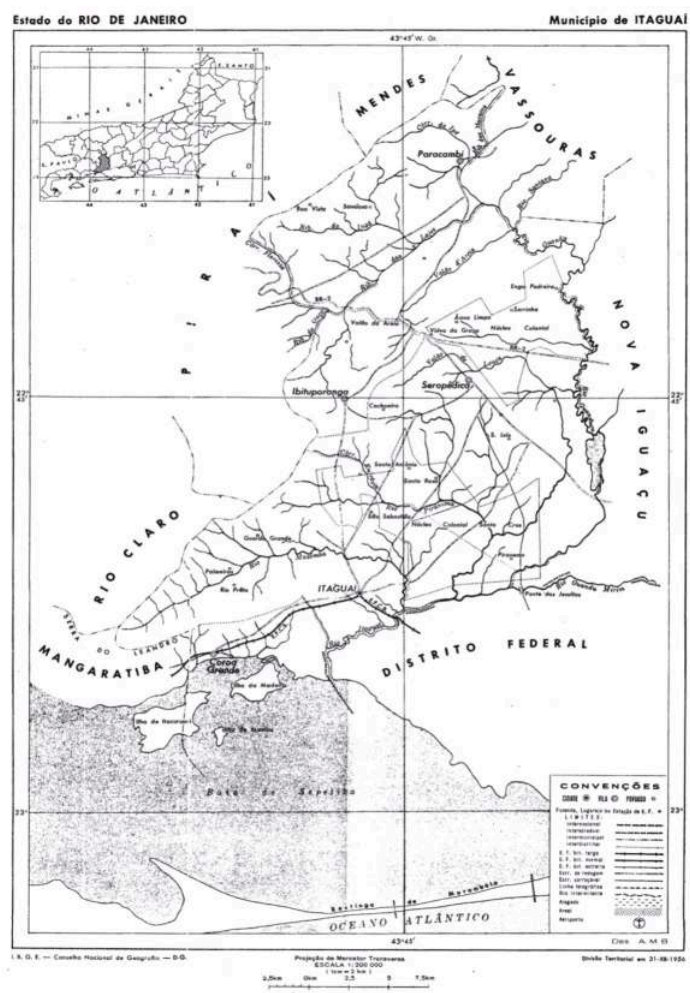

Fonte: IBGE/CNG, 1956

Esse é outro assunto, a passagem do rural ao urbano (ou, ainda, o seu entremeio "rurbano") na região, que certamente renderá muitos outros debates no futuro, e que condiciona o ritmo histórico daquilo que sedimenta o sentido do atual OMRJ. Em outras palavras, essa região, longe de se constituir tão-somente em um atributo "natural" dado pela conformação da bacia hidrográfica, ou pelas particularidades da composição geomorfológica de seu sítio ou da cobertura vegetal, ${ }^{15}$ revela o seu conteúdo histórico por intermédio do cruzamento entre as formas da propriedade e os projetos de desenvolvimento local, que ao menos desde o período colonial aportam, seguindo variados ritmos ao longo dos últimos cinco séculos, um processo de economização do território, cujo resultado manifesta-se, no presente momento, na qualidade da urbanização e de sua mobilização crítica, em várias direções. Se desde o momento inicial de construção do Estado e território brasileiros, o atual OMRJ apresenta-se como um território cercado, vigiado, controlado e mesmo requerido pelas mais diversas forças políticas, sociais e econômicas, há que se compreender outras nuances da geografia dessa região, e desta vez por intermédio da composição de seus caminhos, limites e fronteiras. A partir daqui, portanto, nos dirigimos ao último tópico deste artigo.

\section{Emancipações: caminhos e fronteiras fluidas}

Pouco mais de 60 anos atrás, Sérgio Buarque de Holanda publicava a obra "Caminhos e fronteiras". Apesar de, naquela obra, o historiador referir-se muito mais diretamente à 
força territorial expansiva a partir do planalto de Piratininga ${ }^{16}$ por parte de indígenas e, simultaneamente, elementos da colonização portuguesa, entre os séculos 16 e 19, sua obra trazia interessantes elementos inscritos na lógica e na dinâmica do cotidiano desses caminhantes. Logo no início do texto, o autor define desse modo seu recorte analítico:

A visão e orientação unitárias a que se sujeita, assim, a matéria deste livro se acham sugeridas, aliás, no seu próprio título. Se o aceno ao caminho, 'que convida ao movimento', quer apontar exatamente para a mobilidade característica, sobretudo nos séculos iniciais, das populações do planalto paulista - em contraste com as que, seguindo a tradição mais constante da colonização portuguesa, se fixaram junto à marinha -, o fato é que essa própria mobilidade é condicionada entre elas e irá, por sua vez, condicionar a situação implicada na ideia de 'fronteira'. Fronteira, bem entendido, entre paisagens, populações, hábitos, instituições, técnicas, até idiomas heterogêneos que aqui se defrontavam, ora a esbater-se para deixar lugar à formação de produtos mistos ou simbióticos, ora a afirmar-se, ao menos enquanto não a superasse a vitória final dos elementos que se tivessem revelado mais ativos, mais robustos ou melhor equipados. (HOLANDA, 2008 [1956]: 12-13)

Se, dentro da respeitável obra de Sérgio Buarque de Holanda, segundo avaliação de Ilana Blaj e Marina Maluf, "Caminhos e Fronteiras" não é apenas o título de uma de suas obras e sim "toda a sua obra, onde a realidade está sintetizada no movimento dos caminhos e nas tensões das fronteiras" (1990, p. 19-20), certamente não consideramos menor, acessório ou casuístico o debate sobre caminhos e fronteiras da atual metrópole do Rio de Janeiro em seu continuum histórico. Segundo nossa acepção, passado, presente e devir compõem as tramas desse debate cujos elementos levantaremos a seguir.

Parágrafos atrás, referimo-nos às perspectivas contemporâneas de regionalização desse recorte espacial, incluindo as que consideravam, de modo mais explícito e mais afeito às perspectivas econômico-territoriais, o aporte recente de investimentos de corte industrial e logístico. Conforme apontamos igualmente, têm crescido substancialmente, nos últimos anos, os estudos acadêmicos que iluminam a lógica territorial desses novos investimentos e que, realmente, põem-se a constituir suas próprias regiões. Os planos advindos do Estado conformam essa estrutura e sedimentam tal(is) regionalização(ões). Por essa razão, conferimos especial atenção, neste texto, ao corte logístico operado por essas iniciativas, que atualizam, de certo modo, determinações que parecem fazer parte desse território há muito tempo. E por essa razão, regressamos mais uma vez a outros momentos históricos decisivos, que de algum modo trazem seus rastros à compreensão da natureza contemporânea dessa região e território.

Em estudo publicado em 2008, Adriano Novaes apresenta uma descrição ou transcrição dos caminhos antigos do território fluminense, mais especificamente aqueles vinculados direta ou indiretamente com o ciclo do ouro, na conexão entre Minas Gerais e Rio de Janeiro, durante o século 18, e o ciclo do café, especificamente no que diz respeito à extensão da atividade cafeeira ao Vale do Paraíba fluminense a partir do início do século 19. Tal tarefa não seria possível sem uma análise dos "relatos, desenhos e aquarelas que retratam as paisagens por onde passaram os viajantes, impulsionados pelos mais diversos motivos", compostas por "primitivas roças para a provisão de mantimentos", "armazéns que abasteciam as tropas de mulas dos carregadores de ouro", "postos de registro que controlavam o tráfego das riquezas minerais extraídas do interior do país", ou engenhos de açúcar com destiladores e moendas, fazendas com plantações de milho, mandioca, arroz ou feijão e, finalmente, a existência de "portos fluviais de cidades que desapareceram" e "povoados ou núcleos que estacionaram no 
tempo" (NOVAES, 2008, p. 54). De um modo geral, portanto, tais paisagens conformaram o ambiente necessário ao desenvolvimento dessas importantes atividades econômicas no Brasil dos séculos 18 e 19. Tais caminhos, portanto, simbolizam e expõem os fundamentos históricos desses momentos. Aliás, se houve a progressiva abertura desses caminhos cruzando o Vale do Paraíba fluminense já a partir do século 17, aproveitando-se inclusive das "velhas picadas abertas pelos índios" (como, por exemplo, a rede de estradas hoje conhecida e turistificada com o selo "Estrada Real", ligando as atuais cidades de Paraty e Rio de Janeiro à região das minas, nas chamadas "cidades históricas" do estado de Minas Gerais), tais caminhos foram sendo aperfeiçoados ou novos caminhos paralelos foram sendo abertos ao longo dos séculos 18 e 19 também para viabilizar o transporte, via tropas de mulas, do café, o chamado “ouro verde" (NOVAES, 2008, p. 59).

Mapa 17: Caminhos entre a atual região do Médio Paraíba e a cidade do Rio de Janeiro nos séculos 17,18 e 19

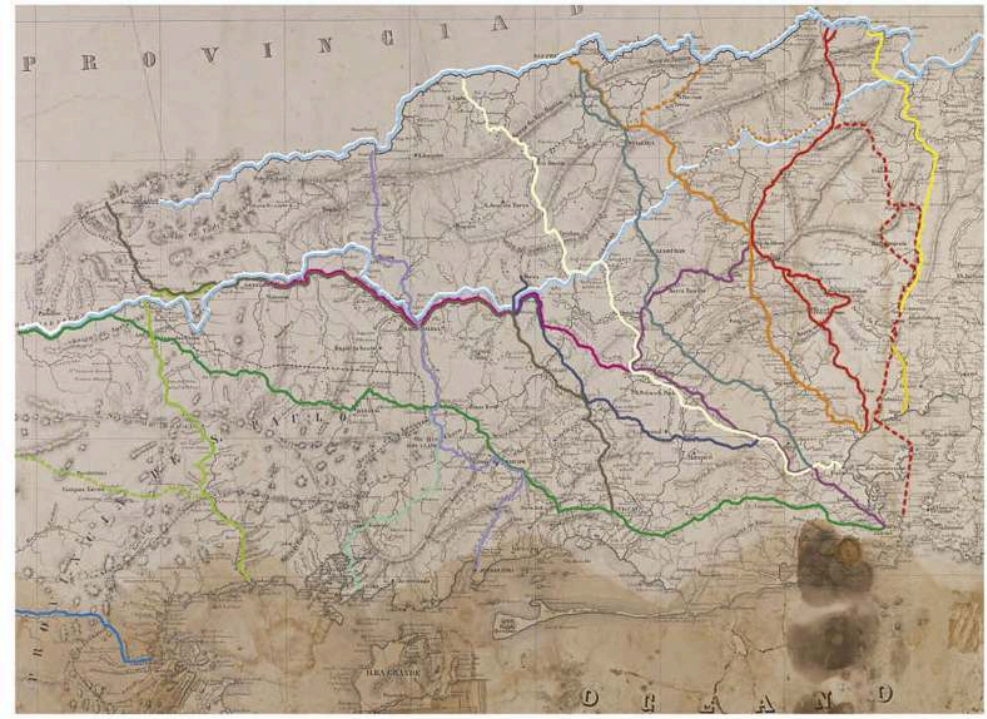

LEGENDA
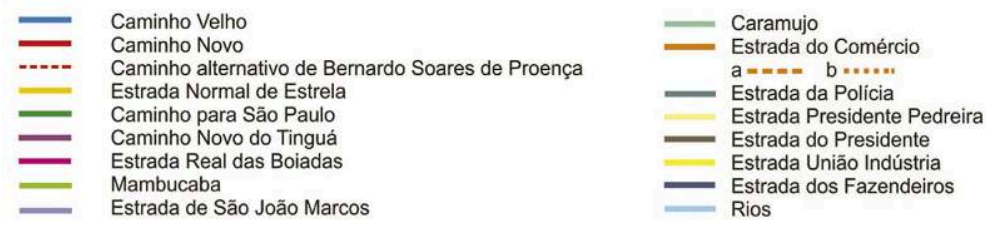

Fonte: NOVAES, 2008, p. 60

Fania Fridman, em estudo publicado também em 2008, com o objetivo de "contribuir no esforço da feitura de uma teoria da urbanização fluminense", almejou "entender o povoamento de caráter planejado pelo interior do Rio de Janeiro ocorrido a partir dos setecentos e decorrer do século 19". Para tanto, a pesquisa, que se circunscreveu ao território ocupado pelos atuais municípios de Vassouras, Miguel Pereira, Paty do Alferes, Mendes, Paulo de Frontin e Paracambi visou demonstrar que o arranjo desse território "nasceu de um plano regional e urbano para o 'sertão do oeste' apoderado pelos coroado e puri, cujo aldeamento e extermínio ocorreram a partir do século 18”, o que teria dado origem "à ocupação 'serra acima' através da abertura de caminhos, da doação de sesmarias em sequência, da instalação de postos de fiscalização e do estabelecimento de freguesias e vilas". Por fim, afirma a autora que "a abertura de 
estradas proporcionava sesmarias ao executor em troca dos serviços prestados bem como isenção de serviço militar, privilégios fiscais e imunidades no campo judicial" (FRIDMAN, 2008, p. 28). Na verdade, essa base social pretérita, advinda de tempos tão longínquos, e que viabilizou a primeira voga de produção em larga escala de um produto tão crucial na economia brasileira daquele tempo, que era o café, revela justamente o sentido de uma região que há muito se põe em uma trama espaçotemporal produtiva de largo calibre e centralidade.

Por fim, para encerrar este tópico, apontamos o traçado do primeiro caminho de terra entre as cidades do Rio de Janeiro e de São Paulo, que durante pelo menos dois séculos tornou-se o principal vínculo entre essas que hoje constituem as duas maiores metrópoles do Brasil, conforme inclusive apresentamos no tópico 1 deste artigo. Conforme a figura anterior, esse caminho, que até a inauguração da Estrada de Ferro Central do Brasil, em 1858 (denominada Estrada de Ferro Dom Pedro II até 1889, data da Proclamação da República), e a conclusão de sua conexão até a cidade de São Paulo (via "Ramal de São Paulo"), em 1875, era a única ligação por terra entre ambas as cidades. A estrada partia do centro do Rio de Janeiro e seu traçado correspondia ao que hoje são várias ruas e avenidas em áreas urbanas no interior do município, atingindo os atuais bairros de Campo Grande e Santa Cruz, nas imediações da sede da Fazenda; em seguida, acorria a Itaguaí e, cruzando o Rio Mazomba e subindo a Serra da Calçada, atingia as proximidades do atual "Mirante do Imperador", em Itaguaí, já no planalto que, em seguida, acessa a antiga povoação de São João Marcos, atualmente pertencente ao Rio Claro (RJ), tomando o caminho de Bananal (SP) e demais localidades ao longo do Vale do Paraíba paulista, até chegar à atual área central da cidade de São Paulo.

Em meio aos estudos e prospecções do PELC/RJ 2045, traçando alternativas para abertura de uma eventual nova rodovia paralela à Rodovia Presidente Dutra entre o entroncamento com a Rodovia Carvalho Pinto, em Taubaté (SP), e a entrada Oeste na RMRJ, em Paracambi e Seropédica, o documento confrontava uma proposta divulgada no "Projeto Sudeste Competitivo", elaborado pela Confederação Nacional da Indústria (CNI) em 2015, ${ }^{17}$ ("traçado 1") e a proposta do próprio PELC ("traçado 2"). O resultado está nos mapas a seguir: 
Mapa 18: Propostas de novas rodovias paralelas à Rodovia Presidente Dutra, entre Taubaté (SP) e a Entrada Oeste da RMRJ

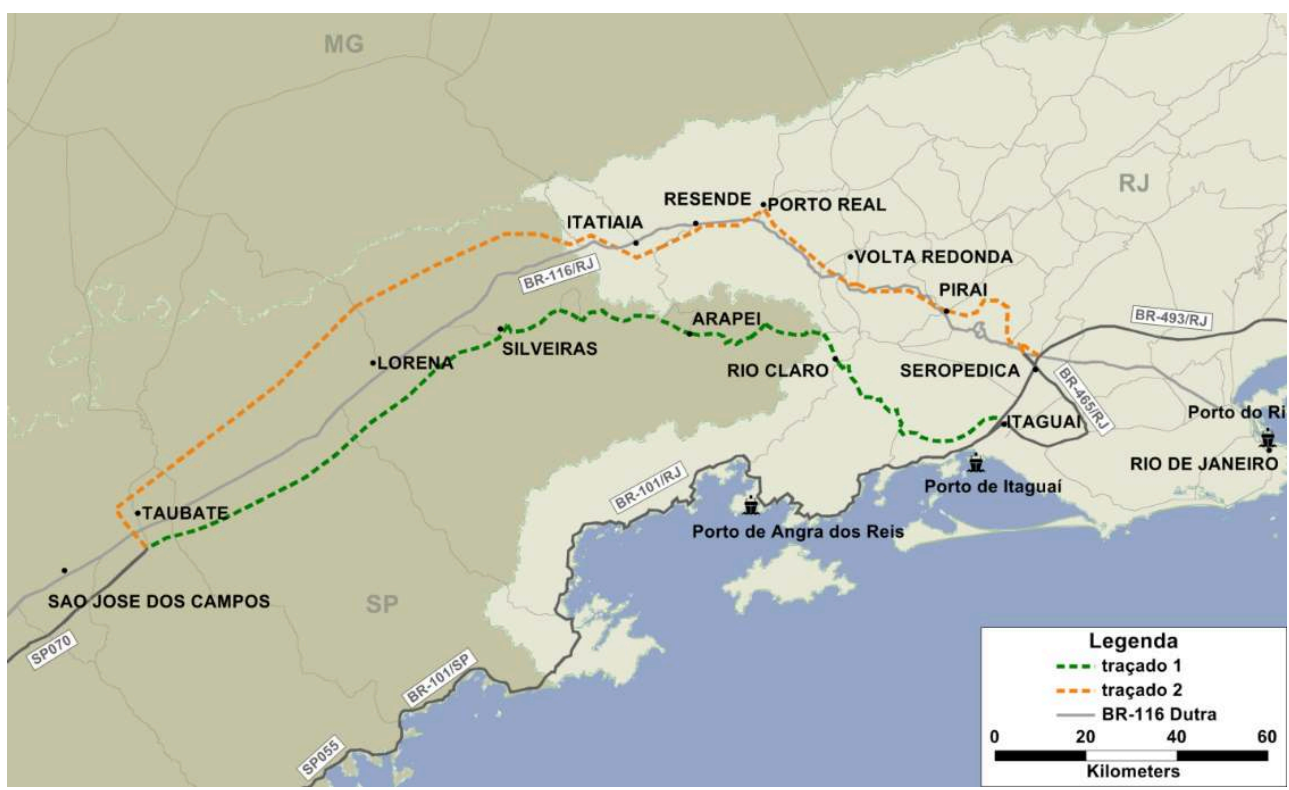

Fonte: RIO DE JANEIRO (Estado), 2016b, p. 141.

Mapa 19: Fluxo de veículos projetados para 2044 (próximo ao horizonte temporal final do PELC/RJ 2045) pela alternativa proposta pelo "Projeto Sudeste Competitivo", perfazendo exatamente o mesmo caminho percorrido pela antiga estrada geral Rio-São Paulo até o final do século 19.

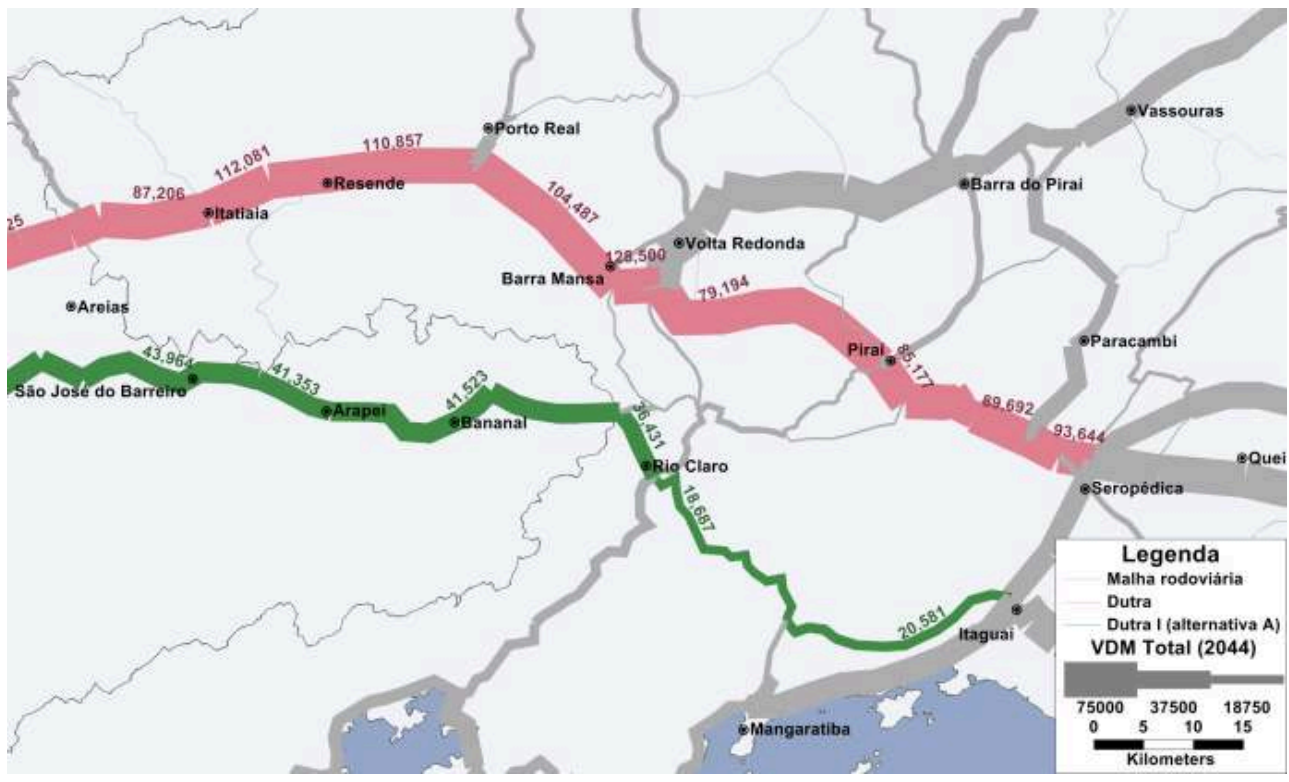

Fonte: RIO DE JANEIRO, 2016b, p. 141

Dentre os "Projetos Estruturantes para a Conexão Rio (Vale do Paraíba) - São Paulo", o PELC pontifica que a Rodovia Presidente Dutra, já com quase 70 anos de idade, é antiga e "precisa de reformas urgentes" quanto à ampliação de sua capacidade de tráfego. Além disso, prossegue o plano:

[...] por mais que não se tenha mostrado viabilidade econômica no longo prazo, este projeto foi considerado estratégico do ponto de vista logístico, por desviar o fluxo da Dutra, e por permitir a implantação do conceito de corredor expresso, como já 
ocorre em São Paulo com os corredores formados pelas rodovias Dutra e Ayrton Senna/Carvalho Pinto e rodovias Anhanguera e Bandeirantes. (RIO DE JANEIRO [Estado], 2016b, p. 140) cumpre ainda aprofundar elementos do que podemos convencionar ser o "empreendedorismo urbano periférico" (OLIVEIRA, 2016, entre outros), cruzando políticas de "desenvolvimento" local à atração de investimentos que, na prática, pouco ou quase nada contribuem positivamente com o enfrentamento das mazelas de uma região cuja marca essencial, muito grosso modo, é a da urbanização onde qualquer coisa que lembre o "direito à cidade" passa a léguas de distância. A precariedade da vida cotidiana de grande parte de sua população é a marca histórica do atual OMRJ, que, desde cedo, tornou-se centralmente estratégico aos interesses econômicos e políticos das mais diversas ordens e escalas. Evidentemente, a escala nacional, inclusive, não pode ser de modo algum menosprezada aqui, já que, conforme demonstramos, traços constitutivos dessa nacionalidade via estratégias do Estado brasileiro em sua indissociabilidade com as estratégias econômicas de variadas ordens historicamente povoaram e seguem povoando a ambiência dessa região.

Igualmente, alguns estudos que têm surgido nos últimos anos vêm desvendar nexos da gênese da propriedade na região, sobretudo no que se refere à Fazenda Real, Imperial ou Nacional de Santa Cruz. Aliás, a despeito da importância e da centralidade desse espaço na história do Brasil e, inclusive, de estudos historiográficos acerca desse recorte datarem ainda do século 19 , acreditamos que muito ainda há para ser feito quanto ao desvendamento da complexa passagem do rural ao urbano nessas terras. Se alguns estudos historiográficos se esmeraram em destrinchar conflitos entre foreiros, arrendatários e posseiros ou mesmo a articulação entre membros do Estado e certos 
indivíduos com ligações diretas via laços de amizade e via outras trocas clientelistas entre o final do século 16 e a primeira metade do século 20 (PEDROZA e OLIVEIRA, H., 2016; PEDROZA, 2018 entre outros), ainda são incipientes os estudos que abordem, de modo mais sistemático, os últimos cinquenta anos do destino dessas terras, mais especificamente o período entre 1970 e 2020 . Se, de um modo geral, outros estudos sobre a urbanização da RMRJ sugerem, de modo mais ou menos explícito, que a extinção dos núcleos de colonização agrícola implantados em meados do século 20 abriram as portas para uma urbanização precária em terras já pouco viáveis para uma pequena produção camponesa e, ao longo do tempo, tornadas economicamente e socialmente desvalorizadas, resta compreender, em uma visão de conjunto, as concretas implicações desses loteamentos. Entendemos aqui, porém, que tais estudos passam muitas vezes por tramas localizadas entre o legal e o ilegal, e certamente conformam a atual ambiência dos grupos paramilitares armados que, vez ou outra, controlam e rentabilizam, ao seu modo e de acordo com suas próprias estratégias, territórios inteiros nessa região.

54 Aliás, esse é outro tema que merece maior aprofundamento, e certamente em uma visão regional de conjunto: as estratégias de grupos paramilitares que atuam no OMRJ. Não é desconhecido o fato de que as milícias que hoje atuam em várias regiões do Estado do Rio de Janeiro tiveram como base fundamental as relações pautadas em uma sociabilidade violenta, já denunciada e/ou destrinchada em muitos fóruns, na região hoje conhecida como Baixada Fluminense. Mas também não podemos nos esquecer que tais relações, além de pautarem o imaginário social a partir das violentas incursões policiais midiatizadas no esteio da guerra às drogas e que visibilizam de modo estereotipado e estigmatizador as favelas localizadas nas áreas mais ou menos centrais da cidade do Rio de Janeiro, também encontraram fértil terreno em uma região que, sobretudo a partir das décadas de 1960 e 1970, começa a se urbanizar efetivamente e a interligar-se à massa urbanizada advinda das Zonas Sul e Norte do município do Rio de Janeiro: trata-se, justamente, da Zona Oeste do município. Assim, é justamente nos bairros da Zona Oeste do Rio de Janeiro, sejam os localizados na Baixada de Jacarepaguá, sejam os localizados na Baixada de Sepetiba, onde essa modalidade criminosa é inaugurada em algum momento do final do século 20 e onde se consolida, tornando tal região quase um laboratório social da resposta de frações da economia capitalista à crescente crise social e política que mostra suas entranhas, de modo espetacular, no Rio de Janeiro das últimas décadas do século 20 e primeiras décadas do século 21. 0 resultado é que, se hoje as investigações policiais, conduzidas com o aval do Poder Judiciário, mostram que tais grupos estão presentes em quase todos os bairros da Zona Oeste do Rio de Janeiro e em todos os demais municípios do OMRJ, alguma coisa diz que essa grande região, em conjunto, também contabiliza essas estratégias de novas rentabilidades. São parte constitutiva, portanto e efetivamente, segundo a nossa avaliação, do processo de reestruturação territorial-produtiva tão investigado por tantos autores. No entanto, entendemos que muito ainda há para ser compreendido nesse sentido, incluído aí os não muito pequenos riscos de tal investida.

Outro campo a ser investigado são as tentativas de desmembramento municipal da AP5 do município do Rio de Janeiro, realizadas pelo menos entre as décadas de 1960 e 1980. Embora este tema esteja muito em consonância com as estratégias de reprodução de grupos políticos e econômicos locais, cujos interesses, em determinados momentos, adquiriram força política o suficiente para influenciar os poderes legislativos do município ou do estado (seja o antigo Estado da Guanabara ou o atual Estado do Rio de 
Janeiro), é notório observar o quanto os limites político-administrativos e sua estabilidade ou instabilidade têm significativa influência no processo de urbanização e metropolização. É de se notar, evidentemente, que tais processos foram observados também em Nova Iguaçu e outras localidades da RMRJ, principalmente ao longo das décadas de 1980 e 1990. Além disso, cumpre destacar que o estabelecimento desses limites políticos condiciona justamente as estratégias de produção das políticas territoriais que reposicionam estratégias de múltiplas ordens, inclusive a afirmação de certas centralidades, como, por exemplo, o bairro e região de Campo Grande.

o reposicionamento do debate sobre centralidades e periferias também se torna elementar, sobretudo em nosso atual contexto histórico, onde o ideário de fragmentação urbana parece ter substituído, no campo das representações, a materialidade dos desenvolvimentos geográficos desiguais em suas múltiplas escalas, inclusive intraurbanas e intrametropolitanas. Há pouco dissenso quanto ao importante papel que o bairro e região de Campo Grande exerce quanto à principal centralidade do OMRJ, sendo classificado em estudo recente, inclusive, como a segunda centralidade mais importante da RMRJ, ficando atrás apenas do centro do município do Rio de Janeiro (IETS, 2016). Junto a esse debate, que julgamos ser absolutamente necessário, principalmente em se tratando desses territórios circundantes à cidade do Rio de Janeiro, nomeados em vários fóruns como periferias metropolitanas, consideramos importante também aprofundar um pouco mais o debate sobre os limites do que entendemos constituir o OMRJ. Dito em outras palavras, em que medida caberia inscrever, por exemplo, a região administrativa de Realengo, no município do Rio de Janeiro, nessa região? Ou, ainda, os municípios de Queimados e Japeri, bem como a região de Cabuçu e Prados Verdes, constitutivos administrativamente do município de Nova Iguaçu? Qual seria, afinal, o papel do município de Paracambi nesse conjunto regional? Ou, ainda, extrapolando os limites oficiais da RMRJ, caberia considerar também o município de Mangaratiba?

Por último, cabe sistematizar um histórico das políticas do Estado e do planejamento para essa região. Considerando os registros aos quais tivemos acesso, não foram poucas, ao longo da história, as iniciativas de planejamento estatal que pautaram esse recorte, $\mathrm{e}$ justamente com o afã de conferir-lhe um desenvolvimento econômico estratégico a determinados interesses mais ou menos hegemônicos. Aliás, se até este momento do texto nos referimos a projetos de corte majoritariamente urbano-industrializantes, é preciso registrar e visibilizar, também, a presença de uma importante produção agrícola até o momento atual, pautada grosso modo na pequena produção camponesa, presente em vários lugares do OMRJ e perfazendo uma intercorrência históricogeográfica com as lutas pela terra nessa região. Além disso, quanto a essa presença resiliente de traços agrários, é necessário notar a presença-ausência do Estado, em todos os seus níveis, sobretudo quanto à assistência às necessidades mais elementares desses produtores, e o possível-impossível da presença dos projetos agroecológicos que, dentre outras coisas, almejam ora reconstituir identidades, lutas e novos possíveis, ora rentabilizar, de modos vários, essas iniciativas. Seja como for, tais hipóteses quanto às políticas estatais de desenvolvimento, de algum modo, devem ainda ser confrontadas com a realização dos pressupostos desse planejamento que, de certo modo, traz desde sempre um conteúdo modernizador. Aqui, entraria, portanto, o que compreendemos ser os traços de uma "modernização retardatária", ainda a ser aprofundada em seus termos teóricos e práticos. 
fim, são múltiplos os problemas e desafios que enfrentaremos a partir daqui, tanto em relação às pesquisas quanto ao nosso envolvimento no campo da atuação prática, envolvendo o mundo do trabalho na universidade e a participação em instituições, organizações, agrupamentos políticos e demais redes associativas que se põem a discutir e a enfrentar os complexos problemas da urbanização desse território e dessa região. É por essa razão que deixamos aqui o testemunho dessa pesquisa, que ainda está iniciando sua trajetória e que ainda tem muito a ser acrescentada com a vivência resiliente de uma região que se (re)produz enquanto tal, na crítica da economia política da urbanização carioca e fluminense e em seus necessários rebatimentos com a mundialidade do capital. E que, de certo modo, anuncia o devir de uma urbanização cada vez mais crítica ou, talvez, desurbanizante. Esse, certamente, será assunto para novas conversas no futuro.

\section{BIBLIOGRAFIA}

ALCÂNTARA, Denise de. A construção de cenários prospectivos em Seropédica: integrando a academia e a coletividade no estudo da paisagem e do território. In: COLÓQUIO QUAPA SEL QUADRO DO PAISAGISMO NO BRASIL, 11, 2016, Salvador. Anais. Salvador, 2016a.

ALCÂNTARA, Denise de. Conflitos socioambientais e o periurbano em Seropédica na Baixada de Sepetiba: nós nas redes, redes sem nós. In: Recôncavo: Revista de História da UNIABEU. Belford Roxo, RJ: UNIABEU, vol. 6, no 11, pp. 28-48, jul./dez. 2016 b.

ALCÂNTARA, Denise de. Sobre as águas do Piranema: potencialidades e fragilidades na ocupação de um território em transformação. In: SEMINÁRIO NACIONAL SOBRE O TRATAMENTO DE ÁREAS DE PRESERVAÇÃO PERMANENTE EM MEIO URBANO E RESTRIÇÕES AMBIENTAIS AO PARCELAMENTO DO SOLO, 3, 2014, Belém. Anais. Belém, 2014.

ALCÂNTARA, Denise de; SILVA, Marcio Rufino e OLIVEIRA, Natália Silva de. A periferia da pobreza na borda oeste metropolitana do Rio de Janeiro. Ocupação, apropriação e (des)estruturação sócioespacial e territorial. In.: ENANPUR, 18, 2019, Natal. Anais..., Natal, 2019.

ALONSO, Deolinda Martinez. Alguns aspectos geográficos do município de Itaguaí. In: Revista Brasileira de Geografia, ano XXII, nº 3, jul./set. 1960, pp. 381-432.

ARAUJO, Regina Célia Lopes. A universidade no contexto urbano: as representações presentes na relação socioespacial entre a Universidade Federal Rural do Rio de Janeiro e a cidade de Seropédica. 2011. 318 p. Tese (Doutorado em Planejamento Urbano e Regional). Universidade Federal do Rio de Janeiro, Rio de Janeiro, 2011.

AZEVEDO, Aroldo de. A cidade de São Paulo. Estudos de geografia urbana. Vol. 1: A região de São Paulo. São Paulo: Companhia Editora Nacional, 1958.

BLAJ, Ilana; MALUF, Marina. Caminhos e fronteiras: o movimento na obra de Sérgio Buarque de Holanda. In: Revista de História, n. 122, pp. 17-46, jan./jul. 1990.

CONSÓRCIO FATOR. Plano de Negócios Referencial - Bloco 3. Projeto de concessão regionalizada dos serviços de abastecimento de água e esgotamento sanitário dos municípios do Estado do Rio de 
Janeiro atualmente atendidos pela CEDAE. Rio de Janeiro, 2020. Disponível em: http:// www.rj.gov.br/consultapublica/documentos/Grupo_5_-_Planos_de_Negocio_Referenciais/ Plano_de_Negocios_Referencial_-_Saneamento_RJ_Bloco_3_Rev.pdf. Acesso em 29 de julho de 2020.

CORREAA, Armando Magalhães. O sertão carioca. Rio de Janeiro: Imprensa Nacional, 1936.

DAMIANI, Amélia Luísa. Espaço e Geografia: observações de método. Ensaio sobre Geografia Urbana a partir da metrópole de São Paulo. 2008. 414 p. Tese (Livre Docência em Geografia Urbana). Faculdade de Filosofia, Letras e Ciências Humanas, Universidade de São Paulo, São Paulo, 2008.

DAMIANI, Amélia Luísa. Urbanização crítica e situação geográfica a partir da metrópole de São Paulo. In: CARLOS, Ana Fani Alessandri e OLIVEIRA, Ariovaldo Umbelino de. Geografias de São Paulo 1: representação e crise da Metrópole. São Paulo: Contexto, 2004.

DEBORD, Guy. A sociedade do espetáculo. Comentários sobre a sociedade do espetáculo. $1^{\mathrm{a}}$ ed. $4^{\mathrm{a}}$ reimpr. Rio de Janeiro: Contraponto, 2003.

DEULCEUX, Sandrine ; HESS, Remi. Henri Lefebvre. Vie, œuvres, concepts. Paris : Ellipses, 2009.

ENGEMANN, Carlos; e AMANTINO, Marcia (org.). Santa Cruz: de legado dos jesuítas a pérola da Coroa. Rio de Janeiro: EdUERJ, 2013.

FARIAS, Heitor Soares de. Bacias aéreas: uma proposta metodológica para o estudo da qualidade do ar em área influenciadas pelo relevo. In: Revista Brasileira de Climatologia, ano 9, vol. 12, jan./jul. 2013, pp. 48-60. Disponível em: https://revistas.ufpr.br/revistaabclima/article/view/30081. Acesso em 8 de agosto de 2020.

FERREIRA, Álvaro; RUA, João; e MATTOS, Regina Célia de. Metropolização do espaço, gestão territorial e relações urbano-rurais: algumas interpretações possíveis. In: GeoUERJ, ano 16, nำ 25, v. 2, 2014, p. 477-504. Disponível em: http://dx.doi.org/10.12957/geouerj.2014.14408. Acesso em 28 de julho de 2020 .

FORTES, Alexandre; OLIVEIRA, Leandro Dias de; e SOUSA, Gustavo Mota de. « A COVID-19 na Baixada Fluminense: Colapso e apreensão a partir da periferia metropolitana do Rio de Janeiro ", Espaço e Economia [Online], 18 | 2020, posto online no dia 21 abril 2020, consultado o 30 julho 2020. URL: http://journals.openedition.org/espacoeconomia/13591; DOI: https://doi.org/10.4000/ espacoeconomia.13591

FRANCO, José Luiz de Andrade e DRUMMOND, José Augusto. Armando Magalhães Corrêa: gente e natureza de um sertão quase metropolitano. In: História, Ciências, Saúde - Manguinhos, Rio de Janeiro, v. 12, n. 3, p. 1033-59, set.-dez. 2005. Disponível em https://doi.org/10.1590/ S0104-59702005000300021. Acesso em 29 de julho de 2020.

FRIDMAN, Fania. As cidades e o café. In: Revista Brasileira de Gestão e Desenvolvimento Regional, v. 4, n. 3 (número especial), pp. 27-48, ago./2008. Disponível em https://www.rbgdr.net/revista/ index.php/rbgdr/article/view/151. Acesso em 29 de julho de 2020.

FRIDMAN, Fania. Donos do Rio em nome do rei: uma história fundiária da cidade do Rio de Janeiro. Zorge Zahar Ed.: Garamond, 1999.

FRÓES, José Nazareth de Souza. O Brasil na rota da seda: uma contribuição para a recuperação, enriquecimento e divulgação da memória de Seropédica, Itaguaí, do Estado do Rio de Janeiro. $2^{\text {a }}$ ed. Seropédica, RJ: EDUR, 2004.

GALVÃo, Maria do Carmo Pereira. Aspectos da geografia agrária do sertão carioca. (1962). In: PIRES DO RIO, Gisela Aquino; e COELHO, Maria Célia Nunes. Maria do Carmo Pereira Galvão: percursos geográficos. Rio de Janeiro: Lamparina; PPGG-UFRJ, 2009. 
GEORGE, Pierre et. al. A Geografia Ativa. 3ª ed. São Paulo: DIFEL, 1973 [1964].

HAESBAERT, Rogério. Regional-Global. Dilemas da região e da regionalização na geografia contemporânea. $2^{\mathrm{a}}$ ed. Rio de Janeiro: Bertrand Brasil, 2014 [2010].

HARVEY, David. 17 contradições e o fim do capitalismo. São Paulo: Boitempo, 2016.

HARVEY, David. Los límites del capitalismo y la teoría marxista. México D.F.: Fondo de Cultura Económica, 1990 [1982].

HOLANDA, Sérgio Buarque de. Caminhos e fronteiras. $3^{\text {a }}$ ed. São Paulo: Companhia das Letras, 2008 [1956].

IETS. Centralidades da Região Metropolitana do Rio de Janeiro. Relatório Final. Rio de Janeiro, julho de 2016. Disponível em: https://www.iets.org.br/IMG/pdf/relatorio_final_centralidades.pdf. Acesso em 4 de agosto de 2020.

JAPPE, Anselm. As aventuras da mercadoria. Para uma nova crítica do valor. Lisboa: Antígona, 2006. LEFEBVRE, Henri. Espace et politique. Le droit à la ville II. $2^{\mathrm{e}}$ éd. Paris : Anthropos, 2000 [1973].

LEFEBVRE, Henri. La survie du capitalisme. La reproduction des rapports de production. $3^{\mathrm{e}}$ éd. Paris : Anthropos, 2002 [1973].

LEFEBVRE, Henri. Le retour de la dialectique. 12 mots-clefs. Paris : Messidor, 1986.

LENCIONI, Sandra. Metropolização do espaço e a constituição de megarregiões. In: FERREIRA, Álvaro; RUA, João; e MATTOS, Regina Célia de. Desafios da metropolização do espaço. Rio de Janeiro: Consequência, 2015a.

LENCIONI, Sandra. Região e Geografia. 1ª ed. $1^{\mathrm{a}}$ reimpr. São Paulo: EDUSP, 2003 [1999].

LENCIONI, Sandra. Urbanização difusa e a constituição de megarregiões. In: E-metropolis, ano 6, no 22, set. 2015b, pp. 6-15. Disponível em http://emetropolis.net/artigo/167?name=urbanizacaodifusa-e-a-constituicao-de-megarregioes-o-caso-de-sao-paulo-rio-de-janeiro. Acesso em 28 de julho de 2020.

LOURAU, René. A análise institucional. 2ª ed. rev. Petrópolis, RJ: Vozes, 1995 [1970].

MARTINS, Eduardo Monteiro; FORTES, Júlio Domingos Nunes; RIBEIRO, Gilberto Pessanha; e PEREIRA, Marcus Felipe Mourão. Utilização do Sistema de Informação Geográfica como ferramenta para gestão do monitoramento da qualidade do ar na Região Metropolitana do Rio de Janeiro. In: Engenharia Sanitária e Ambiental, Ed. Especial, 2014, pp. 43-49. Disponível em: https:// www.scielo.br/pdf/esa/v19nspe/1413-4152-esa-19-spe-0043.pdf. Acesso em 8 de agosto de 2020.

MOREIRA, Ruy. 0 pensamento geográfico brasileiro: as matrizes da renovação. $2^{\mathrm{a}}$ ed. São Paulo: Contexto, 2012 [2009].

NOVAES, Adriano. Os caminhos antigos no Território Fluminense. Rio de Janeiro: Instituto Cultural Cidade Viva, 2008. Disponível em http://www.institutocidadeviva.org.br/inventarios/sistema/ wp-content/uploads/2008/06/oscaminhosantigos.pdf. Acesso em 29 de julho de 2020.

OLIVEIRA, Floriano Godinho de; e OLIVEIRA, Leandro Dias de. Espaço metropolitano, regionalização da economia e reestruturação produtiva no estado do Rio de Janeiro, Brasil. In: Cuyonomics. Investigaciones En Economía Regional, 3(5), 39-65, 2020. Disponível em: http:// revistas.uncu.edu.ar/ojs/index.php/cuyonomics/article/view/3601. Acesso em 28 de julho de 2020.

OLIVEIRA, Leandro Dias de. A emersão da região logístico-industrial do Extremo Oeste Metropolitano fluminense: reflexões sobre o processo contemporâneo de reestruturação 
territorial-produtiva. In: Espaço e Economia [Online], 7 | 2015, posto online no dia 12 abril 2016, consultado o 28 julho 2020. URL: http://journals.openedition.org/espacoeconomia/1814; DOI: https://doi.org/10.4000/espacoeconomia.1814.

OLIVEIRA, Leandro Dias de. As "fronteiras" da Região Metropolitana do Rio de Janeiro: mudanças territoriais e ajustes no circuito econômico-produtivo. In: The Overarching Issues of the European Space - a strategic (re)positioning of environmental and ..., Porto, Fac. Letras Univ. Porto, 2019, pp. 344-354. (DOI: 10.21747/9789898969149/fron). Disponível em: https://ler.letras.up.pt/uploads/ ficheiros/17251.pdf. Acesso em 28 de julho de 2020.

OLIVEIRA, Leandro Dias de; e ROCHA, André Santos da. "Neodesenvolvimentismo" e reestruturação produtiva. In: The overarching issues of the european space: the territorial diversity of opportunities in a scenario of crisis. Porto: Faculdade de Letras da Universidade do Porto, 2014, pp. 126-142. Disponível em: https://ler.letras.up.pt/uploads/ficheiros/13200.pdf. Acesso em 28 de julho de 2020.

OLIVEIRA, Max Fabiano Rodrigues de. Do café à policultura: Fazendeiros, lavradores foreiros e as transformações na estrutura fundiária de São Francisco Xavier de Itaguaí (1850-1900). 2015. 119p. Mestrado (Dissertação em História). Instituto de Ciências Humanas e Sociais, Universidade Federal Rural do Rio de Janeiro, Seropédica, 2015.

OLIVEIRA, Patrícia Mathias de. Empreendedorismo Urbano Periférico: um estudo sobre os municípios da Borda Oeste Metropolitana do Rio de Janeiro. 2017. 161 p. Dissertação (Mestrado em Desenvolvimento Territorial e Políticas Públicas). Instituto de Ciências Sociais Aplicadas, Universidade Federal Rural do Rio de Janeiro, Seropédica, 2017.

PEDROSA, Breno Viotto. Pierre George, um ilustre desconhecido. In: Geographia (UFF), vol. 15, n. 29, p. 99-117. Disponível em: https://doi.org/10.22409/GEOgraphia2013.v15i29.

PEDROZA, Manoela da Silva. Capítulos para uma história social da propriedade da terra na América Portuguesa. O caso dos aforamentos na Fazenda de Santa Cruz (Capitania do Rio de Janeiro, 1600-1870). 2018. 663 p. Tese (Doutorado em História). Instituto de História, Universidade Federal Fluminense, Niterói, 2018.

PEDROZA, Manoela da Silva; e OLIVEIRA, Henrique Dias Sobral. Novos proprietários e velhas disputas pela apropriação de terras públicas na Primeira República: Fazenda Nacional de Santa Cruz, Rio de Janeiro, 1891-1933. In: Revista Em Perspectiva [On Line], v. 2, n. 1, 2016. Disponível em: http://periodicos.ufc.br/emperspectiva/issue/view/827/264. Acesso em 30 de julho de 2020.

PEREIRA, Tatiana Cotta Gonçalves. A igualdade na Federação Brasileira e seus efeitos desiguais na reprodução do espaço metropolitano do Rio de Janeiro. 2015. 234 p. Tese (Doutorado em Sociologia e Direito). Instituto de Ciências Humanas e Filosofia, Universidade Federal Fluminense, Niterói, 2015.

RIO DE JANEIRO (Estado). Plano Estratégico de Desenvolvimento Urbano Integrado: Modelar a Metrópole. Produto 18. Tomo II. Rio de Janeiro: Câmara Metropolitana / Consórcio QuantaLerner, 2018.

RIO DE JANEIRO (Estado). Plano Estratégico de Logística e Cargas do Estado do Rio de Janeiro. Documento 19 - Componente 9. Relatório Síntese - Tomo I. Levantamento de dados. Modelos de transporte. Custos logísticos. Rio de Janeiro: Secretaria de Estado de Transportes, 2016a.

RIO DE JANEIRO (Estado). Plano Estratégico de Logística e Cargas do Estado do Rio de Janeiro. Documento 19 - Componente 9. Relatório Síntese - Tomo II. Levantamento de dados. Modelos de transporte. Custos logísticos. Rio de Janeiro: Secretaria de Estado de Transportes, 2016b. 
RIO DE JANEIRO (Estado). Relatório Anual da Qualidade do Ar no Estado do Rio de Janeiro 2009. Rio de Janeiro: Secretaria de Ambiente e Instituto Estadual do Ambiente (INEA), 2009.

RIO DE JANEIRO (Estado). Secretaria de Estado de Meio Ambiente e Desenvolvimento Sustentável (SEMADS). Bacias Hidrográficas e Rios Fluminenses. Síntese Informativa por Macrorregião Ambiental. Vol. 3. Cooperação Técnica Brasil-Alemanha, Projeto PLANÁGUASEMADS/GTZ. Rio de Janeiro: SEMADS, 2001.

SANTOS, Milton. A Natureza do Espaço: técnica e tempo, razão e emoção. São Paulo: Edusp, 2002 [1996].

SARMENTO, Carlos Eduardo Barbosa. Pelas veredas da capital. Magalhães Corrêa e a invenção formal do sertão carioca. Rio de Janeiro: CPDOC, 1998.

SILVA, Henrique Dias Sobral e OLIVEIRA, Max Fabiano Rodrigues de. Fazenda Jesuítica, Imperial, Nacional de Santa Cruz: da acumulação fundiária à colonização agrícola dirigida (Fazenda Nacional de Santa Cruz, Rio de Janeiro, 1850-1930). In: Revista do Arquivo Geral da Cidade do Rio de Janeiro, n.14, 2018, p.169-191. Disponível em http://wpro.rio.rj.gov.br/revistaagcrj/fazendajesuitica-imperial-nacional-de-santa-cruz-da-acumulacao-fundiaria-a-colonizacao-agricoladirigida-fazenda-nacional-de-santa-cruz-rio-de-janeiro-1850-1930/. Acesso em 29 de julho de 2020.

SILVA, Henrique Dias Sobral. Nas tramas da colonização: uma História Social dos colonos e da colonização agrícola em Santa Cruz (Estado do Rio de Janeiro / 1930-1968). 2017. 212 p. Dissertação (Mestrado em História). Universidade Federal Rural do Rio de Janeiro, Seropédica, 2017.

SILVA, Marcio Rufino. A (re)produção do urbano nas tramas da metrópole: Operação Urbana Consorciada Vila Sônia. 2013. 455 p. Tese (Doutorado em Geografia Humana). Faculdade de Filosofia, Letras e Ciências Humanas, Universidade de São Paulo, São Paulo, 2013.

SILVA, Robson Dias da. Estrutura industrial e desenvolvimento regional no Estado do Rio de Janeiro (1990-2008). 2009. 231 p. Tese (Doutorado em Desenvolvimento Econômico). Instituto de Economia, Universidade Estadual de Campinas, Campinas, 2009.

SILVEIRA, Maria Laura. Uma situação geográfica: do método à metodologia. In: Revista Território, ano IV, n. 6, jan./jun. 1999. Disponível em: http://www.laget.eco.br/pdf/06_3_silveira.pdf. Acesso em 29 de julho de 2020.

SOJA, Edward Soja. Writing the city spatially. In: City: analysis of urban trends, culture, theory, policy, action, 7:3, 269-280, 2003. Disponível em http://dx.doi.org/10.1080/1360481032000157478. Acesso em: 28 de julho de 2020.

SOJA, Edward. Para além de Postmetropolis. In: Revista UFMG, n. 20, 137-167, 2013. Disponível em: https://www.ufmg.br/revistaufmg/downloads/20/7-

para_alem_da_postmetropolis_edward_soja.pdf. Acesso em: 28 de julho de 2020.

SOUTO, Adriana Branco Correia. As Comissões Federais de Saneamento da Baixada Fluminense (1910/1933). 135 p. Dissertação (Mestrado em Desenvolvimento Territorial e Políticas Públicas). Instituto de Ciências Sociais Aplicadas, Universidade Federal Rural do Rio de Janeiro, Seropédica, 2016.

TANGARI, Vera Regina; REGO, Andrea Queiroz; MONTEZUMA, Rita de Cássia. O Arco Metropolitano do Rio de Janeiro. Integração e fragmentação da paisagem metropolitana e dos sistemas de espaços livres de edificação. Rio de Janeiro: PROARQ/FAU-UFRJ, 2012. 
TUBBS FILHO, Décio; ANTUNES, Julio Cesar; e VETORAZZI, Janaína Silva (org.). Bacia Hidrográfica dos Rios Guandu, da Guarda e Guandu-Mirim. Experiências para a gestão dos recursos hídricos. Rio de Janeiro: Comitê da Bacia Hidrográfica Guandu / INEA, 2012.

VIANNA, Marcio Albuquerque. A agricultura familiar em Seropédica-RJ: gestão social, participação e articulação dos atores do Polo de Conhecimento Local em Agropecuária. 2017. 252 p. Tese (Doutorado em Ciência, Tecnologia e Inovação em Agropecuária). Universidade Federal Rural do Rio de Janeiro, Seropédica, 2017.

\section{NOTAS}

1. O método regressivo-progressivo, em Lefebvre, advém de sua leitura de textos fundamentais da madureza de Karl Marx, em particular "O Capital" e os "Grundrisse". Sandrine Deulceux e Remi Hess, a esse respeito, escrevem que Lefebvre, a partir de sua leitura principalmente desses textos de Marx, "[...] desenvolveu um método de leitura dos fatos sociais, o método regressivo-progressivo, forma do pensamento dialético, que consiste em partir do atual e, em seguida, regressar ao passado. Isso não é o método histórico, já que esse consiste em instalar-se no passado e tentar ver o que ocorreu, o que aconteceu a esta ou aquela época. Nessa perspectiva, o historiador extrai em seguida as analogias, as comparações, as consequências... O método que Henri Lefebvre traz da obra de Marx consiste, no entanto, em partir do que existe. Para Marx, era o capitalismo, o capitalismo industrial com suas implicações, incluindo o mercado mundial [...]. A partir do atual que analisamos, regressamos lentamente às condições dessa realidade atual. Tenta-se revelar, através desse procedimento regressivo, o que precedeu esse presente. Em seguida, retomamos o processo em sentido contrário para esclarecer, elucidar, desdobrar, desenvolver... Tenta-se ver todos os possíveis (as 'virtualidades') contidas na situação presente. Tenta-se, assim, esclarecer o futuro, tentando atualizar o possível e o impossível. A originalidade de Lefebvre, ainda que se encontre o princípio desse método em Marx, é aplicar às formas sociais concretas a nação, a comunidade camponesa, o urbano, o Estado etc" (DEULCEUX e HESS, 2009, p. 74-75, trad. nossa). Henri Lefebvre, por sua vez, define desse modo a sua proposta. "Ao invés de seguir um tempo linear, de finalidades previsíveis, [uma história mais complexa] tentará ligar tempos múltiplos, as gêneses, as interferências e descontinuidades (com bifurcações, pontos ambíguos, rupturas e catástrofes). O que não quer dizer uma história fragmentada, mas diversificada e reunida por uma concepção, a da "gênese da história", de seu começo ao seu fim. O que significa uma problemática para além da história, portanto "filosófica", ainda que em um sentido paradoxal. [...] Reconsiderado dessa perspectiva, o conhecimento histórico poderia 'servir' sem rebaixar-se. 0 procedimento regressivo (indo do presente ao passado para esclarecer o passado pelo que se tornou e pelo que aconteceu) e progressivo (retornando ao presente a partir de suas múltiplas e complexas condições, para "analisálo" não sem vislumbrar uma "explicação" dificilmente exaustiva) permitiria explorar o possível” (LEFEBVRE, 1986, p. 47).

2. Ruy Moreira define assim o contexto da publicação de "A Geografia Ativa". "Ao tempo que [o] movimento de renovação ocorre na geografia de âmbito anglo-saxônico [Moreira refere-se, aqui, à New Geography, inaugurada por Fred Schaefer, em 1953, com evidente aproximação do corpus da Geografia a modelos matematizáveis, em uma 
epistemologia influenciada pelo Círculo de Viena], na de âmbito francês são outros os caminhos, vindo na forma da proposta da geografia ativa. Denomina-se geografia ativa à fórmula que os geógrafos de inspiração marxista, Pierre George à frente, dão aos problemas da fragmentação e os criados pela emergência de uma geografia aplicada. $O$ ponto de referência é o texto de abertura de Geografia ativa, de caráter normativo, "Problemas, doutrina e método", de autoria de George. [...] Para George está, antes de tudo, na clara definição dos fundamentos e em seu caráter praxeológico autônomo e independente o parâmetro de uma Geografia voltada para os problemas reais de cada tempo. [...] Há, diz, que ressaltar, sobretudo, seu caráter de ciência do espaço e do todo, reunindo em seu campo de visão e em seu entrelaçamento a parte e o todo, tudo em termos de espaço, espaço e todo se confundindo à medida que este é explicado e objeto de explicação por intermédio daquele. Isso significa ter o geógrafo que saber lidar com a diversidade de escalas de tempo e de espaço que é própria da heterogeneidade dos fenômenos com que a Geografia lida. Em particular, com a escala do tempo-espaço da técnica. A equação desse desafio está para ele no conceito de situação." (MOREIRA, 2012 [2009], p. 41). Amélia Damiani, a partir de sua leitura da obra de Pierre George, traz as seguintes asserções. "A Geografia, o tempo todo, está incluída neste possível-impossível de relacionar fenômenos de natureza tão diversas. Ora, tendendo a discernir a questão geoecológica com acuidade pormenorizada de tratamento físico-ambiental e, num salto no abismo, podendo-se escolher estratégias políticas para sua administração, passando por cima da natureza intrínseca do que é o institucional numa época como a nossa: aquela do atrelamento do político com o econômico, inclusive, de modo degradado, nos termos de um Estado de urgência, colado na economia e, portanto, servindo-a. Ora, de um ângulo complicado, tratando a questão social, sob a ótica do espacial. Uma Geografia sistêmica conduziu os estudos de Geografia Física e uma Geografia Crítica refletiu a Geografia Humana que estudava os fenômenos modernos e sociais. No primeiro caso, a noção de geossistemas demarca os estudos em Geografia Física; no segundo caso, no interior da Geografia Humana, chegou a prevalecer a influência marxista e através dela desde a noção de valorização do espaço até a inclusão da possibilidade de se pensar em uma dialética espacial. Dialetizar o acervo conceitual da Geografia, diante dessas diferenças, seria uma tarefa bastante complexa, apenas se situa aqui o liame e, ao mesmo tempo, a divisão que a constitui internamente" (DAMIANI, 2008, p. 22). Por fim, um texto mais recente, de Breno Pedrosa, põe em questão a perenidade das posturas políticas de Pierre George nos quadros do marxismo político tradicional, representado em sua militância no partido comunista. Desse modo, afirma Pedrosa que "George foi um dos principais defensores do binômio plano central e ação regional e, nesse sentido, a publicação do livro 'Geografia Ativa' [...] com seus alunos posiciona a defesa de um ponto de vista e de uma proposta para o novo ciclo do planejamento francês. Aqui, o diagnóstico dos problemas regionais, a partir de seu enquadramento histórico e de sua situação geográfica, permite que o geógrafo atue em equipes multidisciplinares apresentando soluções para os problemas. Entretanto, a grande diferença do resto de sua carreira é que, se anteriormente o planejamento tinha um viés político ligado à construção do socialismo e às ideias do partido, agora, depois do rompimento com os comunistas, o plano deve ser neutro. $O$ diagnóstico idôneo deve ser submetido aos políticos que tomaram as decisões coletivas acerca do que deve ou não ser feito" (PEDROSA, 2013, p. 109). Em um momento anterior do texto, aliás, afirma Pedrosa que George, e isso parece ocorrer de modo mais nítido ao longo da década de 1960, "vai retirando suas referências ao marxismo e aproximando-se das ideias de 
Fernand Braudel sobre a longa duração e sobre a técnica como uma variável que fundamenta a relação entre homem e meio" (2013, p. 108). Seja como for, considerando inclusive essas controvérsias, muito ainda está para ser problematizado e construído acerca dos últimos 50 ou 60 anos da trajetória da Geografia brasileira, sobretudo quanto aos debates e (des)encontros levantados pelos autores citados.

3. David Harvey, em um texto mais recente, retoma essa tese, desta vez com os seguintes argumentos. "Aglomeração produz centralização geográfica. 0 processo molecular da acumulação do capital converge, por assim dizer, para a produção de regiões econômicas. Fronteiras são sempre nebulosas e permeáveis, mas fluxos interconectados em determinado território geram uma coerência suficientemente estruturada para destacar a área geográfica como distinta. [...] Em geral, a coerência estruturada se estende muito além das mudanças econômicas e engloba atitudes, valores culturais, crenças e até grupos religiosos e afiliações políticas. A necessidade de produzir e manter bens coletivos requer a existência de um sistema de governo, de preferência formalizado em sistemas de administração dentro da região. [...] As classes dominantes e as alianças de classe hegemônicas podem conceber e conceder um caráter específico à atividade política e econômica da região. As economias regionais constituem um mosaico frouxamente interligado de desenvolvimento geográfico desigual, no interior do qual regiões ricas tendem a ficar mais ricas, enquanto regiões pobres tendem a ficar mais pobres" (HARVEY, 2016, p. 141-142). Convidamos o leitor, inclusive, a avançar no texto, onde o debate sobre a região e os desenvolvimentos geográficos desiguais é afiliado aos ajustes espaço-temporais, via estabelecimento de novas divisões territoriais do trabalho, processos de desvalorização massivamente territoriais (o autor cita o exemplo da destruição econômica da região de Detroit, no conhecido "rust belt" do Nordeste dos Estados Unidos), o problema constante da produção de excedentes de capital, a exploração de capitais e o papel do crédito.

4. Outras importantes e ainda recentes contribuições sobre o conceito de região e que se aproximam em maior ou menor grau do propósito deste texto, de discutir os fundamentos da região e regionalização em contato com a urbanização e a metropolização, bem como processos de territorialização, podem ser listadas a seguir. "A nosso ver, a grande dificuldade dos geógrafos em enfrentar a questão da unidade de sua disciplina encontra, também, razões práticas. Tradicionalmente, como se sentissem frágeis diante da questão, sempre têm buscado atribuir um pai à Geografia, em vez de assumirem a responsabilidade da renovação. [...] Na nossa opinião, a questão da unidade, é bom frisar, não diz respeito à Geografia Regional, ela se constitui uma questão central da própria disciplina geográfica. Na medida em que a Geografia deixou de ser considerada uma ciência de síntese, a perspectiva regional não pode mais se colocar como uma solução para os impasses teóricos da disciplina. A emancipação da Geografia, prisioneira da palavra 'região', significou o abandono e a desconsideração de importantes questões teóricas da ciência geográfica" (LENCIONI, 2003 [1999], p. 203-204). "Partindo do pressuposto de que toda espacialidade envolve dimensões (sempre imbricadas), como a econômica, a política, a cultural, a social (em sentido mais estrito) e a ambiental, propomos então trabalhar a regionalização a partir da imbricação, ou melhor, da des-articulação das seguintes dinâmicas ou processos espaciais e/ou territoriais mais gerais, cada um deles focado prioritariamente em uma determinada dimensão do espaço: a) funcionalização, privilegiando as transformações econômicas através do espaço; b) controle ou dominação territorial, em perspectiva mais estritamente social; c) simbolização e/ou identificação espaço-territorial; d) 
precarização e contenção territorial, em perspectiva mais estritamente social; e) exclusão territorial, em sentido que envolve, sobretudo aqui, questões ditas ambientais. Toda regionalização, em sentido amplo, trataria das formas de des-articulação entre esses distintos - mas inter-relacionados e concomitantes - processos" (HAESBAERT, 2014 [2010], p. 137-138).

5. Presente em vários momentos da obra de Soja, o próprio autor assim define a palavra e o conceito de synekism. "Permita-me ilustrar o potencial de pôr em primeiro plano a perspectiva espacial ao escrever sobre a cidade abrindo alguns novos significados para uma antiga palavra grega que permaneceu quase totalmente ignorada por acadêmicos por cerca de 2000 anos. A palavra é synoikismos, às vezes traduzida ao inglês como synoecism, ou como eu prefiro chama-la, synekism. A raiz dessa palavra é oikos, casa ou morada, a mesma raiz é encontrada em economia (que começou simplesmente como administração da família ou economia doméstica) e ecologia, bem como ecúmeno e equística, um termo mais recente inventado pelo urbanista grego Constantinos Doxiadis para estudar todas as formas de assentamentos humanos. O sufixo mos em synoikismos conota as condições decorrentes, enquanto o prefixo syn refere-se a estar junto. Synoikismos ou synekism torna-se, então, definível como as condições que derivam da habitação conjunta em um local ou espaço particular. [...] O uso mais amplo do termo [...] refere-se à formação da cidade-Estado ou polis, outra palavra grega que virtualmente emerge com conotações urbanas" (SOJA, 2003, p. 273).

6. "Ao se falar em metropolização do espaço deve-se, de imediato, remeter-se a alguns fatos que darão sentido à análise a ser efetuada. 0 primeiro é a consideração de que o fenômeno urbano, ligado à industrialização e à aglomeração (complexos urbanoindustriais), marca das décadas anteriores à atual, vem dando lugar ao fenômeno metropolitano, ligado à desindustrialização e às transformações na organização do trabalho propiciando o aumento de sua precarização, não entendido aqui o trabalho apenas como a força de trabalho enquanto mercadoria, mas do homem que trabalha em um contexto histórico concreto do capitalismo manipulatório [...], à desconcentração $\mathrm{e}$ à 'explosão' da metrópole, isto é, à difusão dos códigos metropolitanos, num sentido amplo dessa imagem, num espaço muito além dos limites das regiões metropolitanas, oficialmente delimitadas. 0 segundo fato refere-se à consideração de que diversos outros processos espaciais estarão afetados por essa transformação de urbano para urbano-metropolitano ou, simplesmente, metropolitano. Especificamente estarão sendo referidos a gestão territorial e as relações urbano-rurais processos percebidos como fortemente marcados pela metropolização do espaço, processos alterados pela dinâmica metabólica entre o espaço-tempo de vida e espaço-tempo de trabalho [...]". (FERREIRA et. al., 2014, p. 478)

7. "Já adiantando o seu significado, podemos recorrer a Marx e com ele à ideia de extração de lucros excepcionais, advindos das diferenças de situação. A busca de lucros excepcionais motiva Marx a refletir sobre a tendência, no capitalismo, da taxa de lucros decrescente. Em que sentido? O avanço das técnicas aplicadas à produção, as novas formas de organização do trabalho sugerem, num dado momento, lucros extraordinários para quem os detém; logo, porque generalizados, tornados parte das médias sociais de lucros. 0 que equivale a dizer que a composição orgânica do capital aumenta e com ela o risco de diminuição das taxas de lucro. A mesma excepcionalidade é própria das diferenças de situação e, por isto, elas não são estáveis. A corrida, movida nesta procura, leva à neutralização das diferenças, quando a situação excepcional 
convenciona-se como novo patamar necessário, quando ela se generaliza. E assim novas possibilidades, e outras posições, são produzidas, sempre com a finalidade de lucros extraordinários. $O$ importante é compreender o movimento nessa busca e a produção, sempre renovada, de situações" (DAMIANI, 2004, p. 45). Outra definição importante do termo "situação geográfica" encontra-se a seguir. "A situação é uma manifestação, um produto provisório e instável do movimento de totalização, enquanto o evento pode ser visto como uma 'unidade' de movimento desse processo. [...] Cabe, assim, à noção de situação geográfica [...] a busca de uma 'unidade do múltiplo', um vínculo de relação entre o individual e o universal. Se isolamos, pois, um desses dois momentos, destrói-se a síntese que todo conceito se propõe conseguir. A situação geográfica cristaliza uma dada divisão territorial do trabalho e revela o caminho da instalação de uma nova divisão territorial do trabalho. Por isso, o pesquisador deve descobrir-inventar a variável-chave, isto é, o problema que comanda um sistema para compreender a produção da unicidade e da diferença numa plantação moderna, num campo de petróleo, numa área regulada pelos imperativos do mercado global. Encarnando os processos de construção histórica do meio técnico-científico-informacional, a situação permitir-nos-ia encontrar as mediações entre o mundo, seus eventos e a vida nos lugares. Assim, a situação reafirma a especificidade do lugar e, metodologicamente, aparece como uma instância de análise e de síntese" (SILVEIRA, 1999, pp. 26-27).

8. A Lei Estadual no 3.239, de 2 de agosto de 1999, instituiu a "Política Estadual de Recursos Hídricos", além de criar o "Sistema Estadual de Gerenciamento de Recursos Hídricos”, regulamentando o art. 261, $\$ 1^{\circ}$, inciso VII, da Constituição Estadual do Rio de Janeiro de 1989. Essa lei fundamentou a criação dos Comitês de Bacia Hidrográfica (CBH's). No entanto, cabe fazermos aqui uma distinção entre a macrorregionalização ambiental da macrorregionalização de bacias hidrográficas, conforme segue. "É importante atentar que a adoção, na parte continental, da bacia hidrográfica como unidade de planejamento e intervenção da gestão ambiental, não deve ser confundida com gerenciamento de recursos hídricos, ou seja, o gerenciamento de um único recurso ambiental - a água - quando realizado no âmbito de uma bacia hidrográfica. Todos os recursos ambientais continentais (água, solos, subsolos, ar, biodiversidade e outros) serão administrados tendo a bacia hidrográfica como unidade básica de gerenciamento, a partir de uma visão integrada e sistêmica. Confundir um com o outro implica em uma redução conceitual, temática e metodológica do gerenciamento por Macrorregião Ambiental" (RIO DE JANEIRO [Estado], 2001, p. 8).

9. No PEDUI-RJ, as principais ações giram em torno dos Programas de Ações Prioritárias (PAPs), que, segundo o texto final, "foram elaborados para alcançar os objetivos propostos até 2040". A seguir, listamos os seis programas: Programa Equilibrar a Metrópole (PEM); Programa Habitar a Metrópole (PHM); Programa Metrópole Inteligente (PMI); Programa Metrópole Sustentável (PMS); Programa Baia Reinventada (PBR); Programa Governar a Metrópole (PGM). Segundo o texto, ainda, "a espacialização das ações no território metropolitano e a compreensão de sua abrangência se deu a partir da definição das Macrorregiões de Planejamento (MDPs), que também foram importante ferramenta na elaboração do Zoneamento Metropolitano" (RIO DE JANEIRO [Estado], 2018, p. 311).

10. Note-se que todo o processo que envolveu a construção do PEDUI envolveu, igualmente, a participação de uma série de entidades e movimentos, que de alguma forma constituíram uma contrapartida a um planejamento que ainda se distancia de um 
efetivo processo de participação e construção social do território. Além da respeitável produção crítica advinda da robusta rede acadêmico-universitária e demais instituições de pesquisa da RMRJ, bem como de incontáveis entidades e movimentos sociais que lutam por uma cidade e uma metrópole verdadeiramente digna e justa para a sua população, destacamos, por exemplo, a participação da Casa Fluminense, que produz inclusive documentos que lastrearam e seguem lastreando a crítica a esse processo de planejamento e, de certo modo, compilam as demandas levantadas em variados fóruns organizados pela entidade. Destaque-se, por exemplo, o documento "Agenda Rio 2030", cuja última atualização data de 2018, disponível no endereço https:// www.casafluminense.org.br/wp-content/uploads/2018/06/Agenda-Rio-2030-v.

2018.pdf. Esse é um assunto, aliás, que certamente renderá muita pesquisa daqui em diante, sobretudo diante dos propósitos que apresentamos neste texto.

11. "Muitos pensam que essa idéia de conservar a natureza com a participação das populações residentes é uma inovação radical dos cientistas sociais e dos ambientalistas brasileiros dos anos recentes. Nesse caso, Corrêa propunha uma associação instituída e organizada, ciente de seus próprios interesses e dos interesses que seriam os da "pátria como um todo". Ele acreditava, portanto, que embora as populações sertanejas tendessem a uma existência mais autônoma e em harmonia com o ambiente, era necessário lhes proporcionar, por meio da educação, uma formação moral e patriótica, além de conhecimentos técnicos. A assistência médica e sanitária deveria lhes garantir os confortos da vida moderna. Em suas andanças pelos locais mais ermos do 'sertão carioca', freqüentemente rejubilava-se com os seus habitantes e com a paisagem na qual viviam e da qual tiravam o seu sustento [...]. Corrêa defendia a necessidade de uma regulamentação eficaz que garantisse a sobrevivência, no Brasil, do que considerava uma natureza inigualável. Assim, em relação à questão do controle sobre a caça, apresentava recomendações que levavam em conta os usos humanos da fauna, da flora e das águas das florestas [...]" (FRANCO e DRUMMOND, 2005, p. 1041-1042).

12. O Decreto Federal 8.319, de 20/10/1910, criou as bases do ensino agronômico no Brasil, instituindo a Escola Superior de Agricultura e Medicina Veterinária (ESAMV) (art. $4^{\circ}$ ), bem como o seu funcionamento, na qualidade de externato, em "próprio nacional, sito em Santa Cruz, no Distrito Federal, ficando-lhe annexas uma fazenda experimental e na estação para ensaio de machinas agricolas instaladas nas terras da propria fazenda de Santa Cruz, sem onus para o Governo" (cf. art. 530, nas Disposições Gerais do referido Decreto). No entanto, o Decreto Federal 8.970, de 14/09/1911, traz o seguinte texto, na íntegra. "Considerando que dos estudos e exames alli effectuados ficou averiguado não prestar a localidade aos fins referidos: 1ำ, por estar collocada a distancia que difficultaria o regimen de externato estatuido no regulamento, além dos embaraços que opporia á organização do pessoal docente; $2^{\circ}$, por se acharem os edificios do referido proprio nacional em estado de ruina, de modo a não permittir seu aproveitamento; $3^{\circ}$, por se ter verificado não serem de natureza variada, como conviria, as terras destinadas á fazenda experimental, accrescendo que a parte mais aproveitavel, quer em vista de sua estructura geologica, quer por ser constantemente invadida pelas marés, não reune as condições necessarias ao ensino experimental e demonstrativo de agricultura; Considerando finalmente, que em todos os paizes os institutos superiores de ensino agronomico teem sua séde nas capitaes ou nas grandes cidades onde já existem estabelecimentos que podem concorrer para maior efficacia e desenvolvimento do ensino; Decreta Art. 1ํㅡ A séde da Escola Superior de Agricultura e Medicina Veterinaria e da estação para ensaios de machinas agricolas será no proprio 
nacional sito á rua General Canabarro n. 42, nesta Capital, e da fazenda experimental, annexa á mesma escola, nos terrenos escolhidos e demarcados na Villa Militar, estação de Deodoro, da Estrada de Ferro Central do Brazil". Ou seja, desde o início da criação da ESAMV, considerada o gérmen da atual UFRRJ, aventou-se a possibilidade de uso dos próprios da então Fazenda Nacional Santa Cruz, o que viria a realizar-se, no entanto, apenas quase quarenta anos depois.

13. Há que se notar, no entanto, a decisiva atuação do engenheiro agrônomo e político paulista Fernando de Sousa Costa (São Paulo, SP, 10/06/1886 - Jacareí, SP, 21/01/1946) que, tendo assumido o cargo de Ministro da Agricultura em novembro de 1937, já na égide do Estado Novo de Vargas, "propôs a criação de vários órgãos relacionados com a economia agropecuária e deu início, em 1938, à construção de um complexo destinado a abrigar o CNEPA [Centro Nacional de Ensino e Pesquisas Agronômicas, criado pelo Decreto-Lei Federal $\mathrm{n}^{0}$ 982, de 23/12/1938], em um terreno situado às margens da estrada que ligava o Rio de Janeiro a São Paulo (atual BR 465), na altura do quilômetro 47 [da Estrada Rio-São Paulo], no antigo distrito de Seropédica, pertencente ao município de Itaguaí, no estado do Rio de Janeiro, campus que hoje abriga a UFRRJ" (ARAÚJO, 2011, p. 113). Interessante notar, do mesmo modo, que o mesmo Fernando de Sousa Costa, enquanto governador-interventor do Estado de São Paulo de 04/06/1941 a 27/10/1945, assinou o Decreto Estadual no 12.401, de 16/12/1941, que reservava a área ao sul do leito da Adutora de Cotia, com todas as benfeitorias existentes, para o Instituto Butantan, e a área remanescente para a localização da futura Cidade Universitária, autorizando o Secretário de Estado da Educação e Saúde Pública a providenciar a elaboração dos estudos e planos de execução das obras do complexo acadêmico-educacional onde funciona, hoje, o campus Butantã da Universidade de São Paulo (SILVA, M., 2013, p. 413) que é, na verdade, o principal campus dessa universidade. Em suma, Fernando de Sousa Costa, responsável também pela fundação do Instituto Biológico e do Parque da Água Branca (conhecido também como Parque Fernando Costa), ambas importantes e icônicas instituições localizadas na cidade de São Paulo, além de nomear o principal logradouro do centro de Seropédica (a Avenida Ministro Fernando Costa corresponde às laterais da Rodovia BR-465, ou antiga Estrada Rio-São Paulo, que atravessa o município) tem uma trajetória que merece profunda investigação (parte de sua biografia está disponível em http://www.fgv.br/cpdoc/ acervo/dicionarios/verbete-biografico/fernando-de-sousa-costa) e que muito interessa aos propósitos deste texto e desta pesquisa e, mais especialmente, reproduz de certo modo a trajetória paulistana/paulista-carioca/fluminense e, mais ainda, uspianaruralina do autor deste artigo. Derivando, isso certamente inspira uma boa conversa sobre Implicação e Análise Institucional (LOURAU, 1995 [1970]), quase uma "egogeografia" que, dia desses, merecerá novos escritos.

14. Vale a pena destacar um trecho dessa importante pesquisa. "[...] Partimos do princípio de que a colonização, distante de ter caminhos e uma finalidade predefinida por projetos governamentais, foi uma experiência de política agrícola e agrária em que foram postulados problemas cujas respostas estiveram abertas à atuação dos indivíduos e não somente aos poderes de comando governamental. Imbuídos de um questionamento sobre a onipotência do Estado sob uma sociedade fraca, trataremos aqui de um palco de dilemas e conflitos cujos desfechos não estavam dados com a emancipação do [NCSC], mas dependiam de arranjos subjetivos, ora individuais ora coletivos. Sendo assim, um olhar minucioso das ações dos personagens do núcleo aponta para o estudo das encenações de poder e contrapoder que, tal como em uma 
peça de teatro, revelam distintas formas da atuação desses sujeitos sobre suas vidas e suas lutas pela garantia de suas condições de colonos e pequenos proprietários" (SILVA, H., 2017, p. 19).

15. A noção de "suporte geobiofísico", no entanto, muito tem a nos ensinar quanto aos ritmos de evolução dessas paisagens, sobretudo no OMRJ. Para tanto, citamos aqui um interessante estudo promovido por um grupo de pesquisadores vinculados ao Grupo Sistema de Espaços Livres (SEL), da UFRJ. "Para compreendermos a transformação da paisagem metropolitana do Rio de Janeiro, faz-se mister uma breve análise da configuração territorial que incorpora os principais elementos estruturais que dão suporte às dinâmicas socioambientais ditam, de forma integrada, o reajuste perene dos elementos, processos e fluxos presentes na paisagem, entendendo que ambos os componentes físicos e socioambientais coevoluem e se ajustam constantemente. [...] Considerando que a paisagem é uma categoria do espaço resultante de ações passadas e presentes, sendo, portanto, um produto da coevolução das sociedades humanas e do meio natural, ou pré-técnico, discutir e planejar a RMRJ implica atribuir o mesmo peso aos elementos da paisagem que viabilizem a sustentabilidade físico-ambiental, os quais são suporte e subsídios ao projetos de desenvolvimento, econômicos e sociais." (MONTEZUMA, Rita; e CINTRA, Danielle Pereira. O Arco Metropolitano do Rio de Janeiro: um marco de transformação da paisagem. In: TANGARI et al., 2012, p. 247).

16. Sítio de boa parte da atual Região Metropolitana de São Paulo, justamente em seu trecho mais densamente urbanizado. Ou, conforme Fernando de Almeida (1958), "A cidade de São Paulo encontra-se assentada numa área de terras altas, a que se tem reservado o nome de Planalto Atlântico. Trata-se de um planalto mais ou menos acidentado, de estrutura complexa, cujas altitudes, no território paulista, apresentam variações compreendidas entre 650 e 1.250 metros. No rumo geral de NW, vai gradualmente perdendo altura, até que suas estruturas mergulham por sob as camadas quase nada perturbadas da grande Bacia Sedimentar do Paraná. Para os lados do Sul, limita-se de maneira brutal, constituindo a Serra de Paranapiacaba e as altas escarpas da Serra do Mar" (AZEVEDO, 1958, p. 113).

17. Mais informaç̃os a respeito do "Projeto Sudeste Competitivo", ver: CNI AGÊNCIA DE NOTíCIAS. Logística do Sudeste necessita de $\mathrm{R} \$ 63,2$ bilhões de investimentos até 2020 para garantir escoamento eficiente da produção. 26 out. 2015. Disponível em: https://noticias.portaldaindustria.com.br/noticias/infraestrutura/logistica-dosudeste-necessita-de-r-632-bilhoes-em-investimentos-ate-2020-para-garantirescoamento-eficiente-da-producao/. Acesso em 30 de julho de 2020.

18. “§ 165. A produção capitalista unificou o espaço, que já não é limitado por sociedades externas. Essa unificação é ao mesmo tempo um processo extensivo e intensivo de banalização. A acumulação das mercadorias produzidas em série para o espaço abstrato do mercado, assim como devia romper as barreiras regionais e legais e todas as restrições corporativas da idade média que mantinham a qualidade da produção artesanal, devia também dissolver a autonomia e a qualidade dos lugares. Essa força de homogeneização é a artilharia pesada que fez cair todas as muralhas da China. § 166. Para tornar-se sempre mais idêntico a si mesmo, para se aproximar da monotonia imóvel, o espaço livre da mercadoria é doravante modificado e reconstruído a todo instante. § 167. Essa sociedade que suprime a distância geográfica recolhe interiormente a distância, como separação espetacular" (DEBORD, 2003 [1967], pp. 111-112). 


\section{RESUMOS}

No texto a seguir, apresentamos uma proposta de sub-regionalização, destacando especificamente um recorte no interior da Região Metropolitana do Rio de Janeiro: trata-se do Oeste Metropolitano do Rio de Janeiro, que compreende, em nossa perspectiva, a totalidade dos territórios dos municípios de Paracambi, Japeri, Queimados, Seropédica e Itaguaí, bem como partes dos municípios de Nova Iguaçu e Rio de Janeiro. Para tanto, dividimos o artigo em três momentos distintos. No primeiro tópico, apresentamos um breve diálogo com algumas teorias da região e regionalização e seu diálogo com o urbano e a metrópole. No segundo tópico, trazemos perspectivas pretéritas e presentes de regionalização desse recorte, indicando seus elementos referentes à gênese da propriedade. E, no terceiro e último tópico, trazemos indicativos da constituição de caminhos e fronteiras nessa região. Por fim, elencamos possíveis desdobramentos de pesquisa, partindo das hipóteses que apresentamos neste artigo.

In the following text, we present a proposal for sub-regionalization, highlighting specifically a section within the Metropolitan Region of Rio de Janeiro: it is the Metropolitan West of Rio de Janeiro, which comprises, in our perspective, the entire territories of the municipalities of Paracambi, Japeri, Queimados, Seropédica and Itaguaí, as well as parts of the municipalities of Nova Iguaçu and Rio de Janeiro. Therefore, we divided the article into three distinct moments. In the first topic, we present a brief dialogue with some theories of the region and regionalization and its dialogue with the urban and the metropolis. In the second topic, we bring past and present perspectives of regionalization of this section, indicating its elements referring to the genesis of the property. And, in the third and last topic, we bring indications of the constitution of paths and borders in this region. Finally, we list possible research developments, based on the hypotheses presented in this article.

Dans le texte suivant, nous présentons une proposition de sous-régionalisation, mettant en évidence spécifiquement une section au sein de la Région Métropolitaine de Rio de Janeiro : il s'agit de l'Ouest Métropolitain de Rio de Janeiro, qui comprend, à notre avis, la totalité des territoires des municipalités de Paracambi, Japeri, Queimados, Seropédica et Itaguaí, ainsi que des parties des municipalités de Nova Iguaçu et Rio de Janeiro. À cet effet, nous avons divisé l'article en trois moments distincts. Dans le premier thème, nous présentons un bref dialogue avec quelques théories de la région et de la régionalisation et son dialogue avec l'urbain et la métropole. Dans le deuxième thème, nous apportons les perspectives passées et présentes de la régionalisation de cette section, en indiquant ses éléments faisant référence à la genèse de la propriété. Et, dans le troisième et dernier thème, nous apportons des indications sur la constitution des chemins et des frontières dans cette région. Finalement, nous listons les évolutions possibles de recherche, sur la base des hypothèses présentées dans cet article.

En el siguiente texto, presentamos una propuesta de subregionalización, destacando específicamente un recorte en el interior de la Región Metropolitana de Río de Janeiro: se trata del Oeste Metropolitano de Río de Janeiro, que comprende, en nuestra perspectiva, la totalidad de los territorios de los municipios de Paracambi, Japeri, Queimados, Seropédica e Itaguaí, así como partes de los municipios de Nova Iguaçu y Rio de Janeiro. Por lo tanto, dividimos el artículo en tres momentos distintos. En el primer tema, presentamos un breve diálogo con algunas teorías de la región y la regionalización y su diálogo con lo urbano y la metrópoli. En el segundo tema, traemos perspectivas pretéritas y presentes de regionalización de este recorte, indicando sus elementos referentes a la génesis de la propiedad. Y, en el tercer y último tema, traemos indicios 
de la constitución de caminos y fronteras en esta región. Finalmente, enumeramos los posibles desarrollos en la investigación, basados en las hipótesis presentadas en este artículo.

\section{ÍNDICE}

Mots-clés: Ouest Métropolitain de Rio de Janeiro ; région et régionalisation ; métropolisation ; chemins et frontières; genèse de la propriété.

Keywords: Metropolitan West of Rio de Janeiro; region and regionalization; metropolization; paths and borders; genesis of the property.

Palabras claves: Oeste Metropolitano de Río de Janeiro; región y regionalización; metropolización; caminos y fronteras; génesis de la propiedad.

Palavras-chave: Oeste Metropolitano do Rio de Janeiro; região e regionalização; metropolização; caminhos e fronteiras; gênese da propriedade.

\section{AUTOR}

\section{MARCIO RUFINO SILVA}

Mestre e Doutor em Geografia Humana pela Universidade de São Paulo (USP). Professor Permanente do Programa de Pós-Graduação em Geografia (PPGGEO) e Associado do Programa de Pós-Graduação em Desenvolvimento Territorial e Políticas Públicas (PPGDT) da Universidade Federal Rural do Rio de Janeiro. Professor Adjunto do Curso de Geografia (Bacharelado e Licenciatura) da UFRRJ, campus Seropédica. Coordenador do grupo de pesquisa "Para uma crítica da Economia Política do Espaço" (UFRRJ) e pesquisador do grupo "Geografia urbana: a vida cotidiana e o urbano" (USP). ORCID: https://orcid.org/0000-0002-0301-1325. Email: marciorufis@gmail.br. 